Review

\title{
Non-Coding RNAs in the Cardiac Action Potential and Their Impact on Arrhythmogenic Cardiac Diseases
}

\author{
Estefania Lozano-Velasco ${ }^{1,2}\left(\mathbb{D}\right.$, Amelia Aranega ${ }^{1,2}$ and Diego Franco ${ }^{1,2, *(D)}$ \\ 1 Cardiovascular Development Group, Department of Experimental Biology, University of Jaén, \\ 23071 Jaén, Spain; evelasco@ujaen.es (E.L.-V.); aaranega@ujaen.es (A.A.) \\ 2 Fundación Medina, 18016 Granada, Spain \\ * Correspondence: dfranco@ujaen.es
}

Citation: Lozano-Velasco, E.;

Aranega, A.; Franco, D. Non-Coding RNAs in the Cardiac Action Potential and Their Impact on Arrhythmogenic Cardiac Diseases. Hearts 2021, 2 , 307-330. https://doi.org/10.3390/ hearts2030026

Academic Editors: Francesco Onorati and Matthias Thielmann

Received: 28 February 2021

Accepted: 25 June 2021

Published: 30 June 2021

Publisher's Note: MDPI stays neutral with regard to jurisdictional claims in published maps and institutional affiliations.

Copyright: (c) 2021 by the authors. Licensee MDPI, Basel, Switzerland. This article is an open access article distributed under the terms and conditions of the Creative Commons Attribution (CC BY) license (https:// creativecommons.org/licenses/by/ $4.0 /)$.

\begin{abstract}
Cardiac arrhythmias are prevalent among humans across all age ranges, affecting millions of people worldwide. While cardiac arrhythmias vary widely in their clinical presentation, they possess shared complex electrophysiologic properties at cellular level that have not been fully studied. Over the last decade, our current understanding of the functional roles of non-coding RNAs have progressively increased. microRNAs represent the most studied type of small ncRNAs and it has been demonstrated that miRNAs play essential roles in multiple biological contexts, including normal development and diseases. In this review, we provide a comprehensive analysis of the functional contribution of non-coding RNAs, primarily microRNAs, to the normal configuration of the cardiac action potential, as well as their association to distinct types of arrhythmogenic cardiac diseases.
\end{abstract}

Keywords: cardiac arrhythmia; microRNAs; IncRNAs; cardiac action potential

\section{The Electrical Components of the Adult Heart}

The adult heart is a four-chambered organ that propels oxygenated blood to the entire body. It is composed of atrial and ventricular chambers, each of them with distinct left and right components, that are connected between them through the atrioventricular valves [1]. Oxygenated blood enters the heart through the pulmonary veins into the left atrium, passes through the atrioventricular mitral valve to the left ventricle and then is expelled to the aorta. Systemic blood is collected into the right atrium through the caval veins, enters the right ventricle along the atrioventricular tricuspid valve, and is subsequently expelled throughout the pulmonary artery into the lungs, before re-entering the heart through the pulmonary veins completing thus a new circulatory cycle [1].

Rhythmic contraction of the heart, leading to alternative systole and diastole contraction phases is controlled by the cardiac conduction system (CCS). The CCS is formed by slow and fast conduction pathways. The slow components are two distinct low conducting and self-firing nodes, the sinoatrial and the atrioventricular node, respectively. The sinoatrial node is located at the junction between the right superior caval vein entrance and the atrial chamber myocardium and is the main pacemaker of the heart [2]. The atrioventricular node is located at the top of the interventricular septum just at the junction between atrial and ventricular myocardium. The fast conducting components of the cardiac conduction system are exclusively located in the ventricular chambers, and are composed by the bundle of His, the left and right bundle branches, and the Purkinje fiber network [2]

At cellular level, the electrical activity of the myocardial cells is governed by an exquisite balance of inward and outward ion currents that configure the cardiac action potential. The cardiac action potential can be divided in at least four different phases. The first phase is initiated with a rapid upstroke of inward sodium currents, leading to the depolarization phase. Subsequently, the repolarization phase is initiated with fine-tuned balance of outward potassium currents, leading to phases two ( $\mathrm{I}_{\mathrm{TO}}$ currents) and three ( $\mathrm{I}_{\mathrm{K}}$ currents) of the cardiac action potential to finally reach the fourth phase of resting 
membrane potential ( $\mathrm{I}_{\mathrm{K} 1}$ currents) [3-5]. During the plateau phase, calcium contraction coupling also takes place, by the activation of the $\mathrm{I}_{\mathrm{Ca}, \mathrm{L}}$ currents followed by mobilization of intracellular calcium from the sarcoplasmic reticulum, throughout the calcium-induced calcium release mechanism [6-8]. This general configuration of the cardiac action potential, although applicable to all cardiomyocytes, displays subtle variations on distinct cardiac regions. Importantly, such variability is due to distinct molecular substrates governing such events, such as for example, the upstroke phase in the cardiac action potential of the cardiac conduction system is governed by cation channels, with limited contribution of the sodium channels $[4,5]$. In addition to the distinct functional properties of the cardiac conduction system, the working myocardium also display significant differences between each cardiac regions-e.g., between atrial and ventricular myocardium—and also within the ventricular myocardium itself-e.g., epicardial vs. endocardial configurations. Such regional differences are mainly motivated by regional differences in the relative contribution of the outward potassium channels governing the rapid $\left(\mathrm{I}_{\mathrm{TO}} ; \mathrm{I}_{\mathrm{Kur}}\right)$, plateau $\left(\mathrm{I}_{\mathrm{Kr}} \mathrm{I}_{\mathrm{Ks}}\right)$, and final $\left(\mathrm{I}_{\mathrm{Ks}} ; \mathrm{I}_{\mathrm{K} 1}\right)$ phases of the cardiac action potential repolarization as well as by the L-type calcium channels in the plateau phase. Finally, it is important to highlight that there are notable species-specific differences in the contribution of the discrete ion currents to the final configuration of the cardiac action potential. Such differences are particularly applicable to the repolarization phase in distinct experimental models such as rat, mouse, pig, and zebrafish as compare to humans, as widely documented elsewhere [9-15].

\section{Non-Coding RNAs, Classification, and Function}

For a long time, it has been considered that most non-coding RNAs (ncRNAs) were indeed non-functional parts of the genome, and therefore attention was focused on coding RNAs. However, human genome sequencing and ENCODE projects identified that more than $80 \%$ of the genome is transcribed into RNA. Surprisingly, only 3\% corresponds to coding RNAs, pointing out to an important biological role for ncRNAs [16,17]. In this context, emerging evidences is progressively reporting the essential roles of ncRNAs in distinct biological settings, including herein cell differentiation, homeostasis, and disease (for recent reviews see [18-21]).

NcRNAs are classified in two different categories according to their nucleotide length. Small non coding RNAs are smaller than 200 nucleotides and include microRNAs, small nucleolar RNAs (snoRNAs), piwi-RNAs (piRNAs) as well as transfer RNAs (tRNAs) and ribosomal RNAs (rRNAs) [22]. On the other land, long non coding RNAs (lncRNAs) are longer than 200 nucleotides and include therein distinct subtypes such as intronic, enhancer, circular, or intergenic lncRNAs [23,24].

MicroRNAs represent the most studied type of small ncRNAs, besides tRNAs and rRNAs. MicroRNAs are 20-22 ribonucleotides in length and they can bind to 3' untranslated region of coding RNAs by base-pair complementary, promoting degradation and/or translational blockage [25-27]. Importantly, microRNAs exert key functional roles in multiple biological settings, such as cell differentiation, growth, and homeostasis [28,29].

LncRNAs, on the other hand, are structurally similar to mRNAs but importantly they do not code proteins [30]. LncRNAs can exert transcriptional and post-transcriptional roles, depending on their subcellular localization, i.e., nuclear vs. cytoplasmic. Within the nucleus, they can act as modulators of nuclear gene expression by regulating the epigenetic landscape, scaffolding transcriptional complex or as decoy molecules, whereas in the cytoplasm they can contribute to microRNA degradation, mRNA stability, and/or protein translation see reviews [31-34].

In this review, we aim to provide a state-of-the-art account of the functional contribution of non-coding RNAs to the configuration of the cardiac action potential as well as their consequences if impaired, leading to arrhythmogenic cardiac diseases. 


\section{Role of ncRNAs in the Cardiac Action Potential}

\section{1. ncRNAs in the Upstroke Phase ( $I_{N a}$ Currents)}

The upstroke phase of the cardiac action potential in fast conducting cells, i.e., atrial and ventricular myocytes, is primarily modulated by the fast $\mathrm{I}_{\mathrm{Na}}$ current $\left(\mathrm{Na}_{\mathrm{V}} 1.5\right)$ with a smaller contribution of $\mathrm{Na}_{\mathrm{v}} 1.8$. Importantly, the function of the pore-forming $\mathrm{Na}_{\mathrm{v}} 1.5$ channel is also modulated by ancillary subunits such as $\mathrm{Na}_{\mathrm{v}} \beta 1-\mathrm{Na}_{\mathrm{v}} \beta 4$ (Figure $1 \mathrm{~A}$ ). SCN5A encodes the voltage-gated $\mathrm{Na}+$ channel Nav1.5. Mutations in $S C N 5 A$ are associated to inherited arrhythmias and cardiomyopathy [35-38]. Moreover, single-nucleotide polymorphisms (SNPs) linked to SCN5A splicing, localization, and function are also associated to sudden cardiac death $[39,40]$. SCN10A encodes the voltage-gated $\mathrm{Na}+$ channel NaV1.8. Importantly, mutations in SCN10A have also been linked to sudden unexplained death [41], atrial fibrillation [42,43], and Brugada syndrome [40,44,45]. Furthermore, SCN5A and $S C N 10 A$ share common regulatory elements that are relevant for cardiac function [46].

Distinct sets of evidence have been provided on the functional roles of microRNAs modulating SNC5A expression. Daimi et al. [47] firstly reported that miR-98, miR-106, miR200, and miR-219 directly regulated human SCN5A while miR-125 and miR-153 regulate it indirectly. Functional analysis in HL1 cardiomyocytes revealed that miR-219 and miR200 have independent and opposite effects on Scn5a expression and thus subsequently on $\mathrm{I}_{\mathrm{Na}}$ sodium current, provoking impaired rhythm contraction of the cardiomyocytes. Importantly, in vivo miR-219 administration abolishes QRS prolongation after flecainide intoxication in mice without altering normal cardiac rhythm (Figure 1B). In addition, Zhao et al. [48] reported that miR-192-5p directly targets human SCN5A, affecting therein the peak $\mathrm{I}_{\mathrm{Na}}$ current density. Furthermore, these authors demonstrated upregulation of miR-192-5p in left atrial biopsies of atrial fibrillation (AF) patients as compared to controls, while $S C N 5 A / \mathrm{Na}_{\mathrm{V}} 1.5$ was downregulated. Curiously, miR-1, a highly expressed microRNA in cardiac development and arrhythmogenic cardiac diseases does not modulate SCN5A expression (Figure 1B) [49]. Additional evidences described by Poon et al. [50] demonstrated that miR-200c can modulate SCN5A expression in human embryonic stem cells (ESC)-derived cardiomyocytes, yet direct biochemical evidences are lacking. In sum, our current understanding of the functional role of microRNAs regulation SCN5A expression is still scarce.

A more indirect dataset has also been reported to influence SCN5A expression in distinct arrhythmogenic contexts. For example, Li et al. [51] identified miR-143 as an upstream regulator of EGR1, which can modulate $S C N 5 A / N a V 1.5$ expression (Figure 1B). Zhang et al. [52] recently identified a synonymous SNP (rs1805126) close to a miR-24 site within the SCN5A coding sequence. They also reported that miR-24 potently suppresses SCN5A expression and $\mathrm{I}_{\mathrm{Na}}$ current and that rs1805126 minor allele highly associates with decreased SCN5A expression in heart failure patients (Figure 1B). Surprisingly, homozygous heart failure patients for rs1805126 minor allele displayed reduced ejection fraction and increased mortality while ventricular tachyarrhythmias were not increased. In the same line of thinking, Daimi et al. [53] screened for plausible genetic alterations in SCN5A as well as five additional candidate genes (GPD1L, SCN1B, KCNE3, SCN4B, and MOG1) associated to Brugada syndrome, within the coding sequence, the flanking intronic and the $5^{\prime}$ and 3'UTR regions. Genetic variants such as hsa-miR-219a-rs107822 and a novel SNP that created an additional miR-1270 binding site (Figure 1B) were identified within the SCN5A 3'UTR, but no relevant coding sequence variants. Thus, most SCN5A variants were localized in non-coding regions. Furthermore, the lack of genotype-phenotype correlations supported the complexity of the genetic bases of Brugada syndrome and it suggests that combination of multiple genetic factors, rather than a single variant is behind the onset of this syndrome. 
A

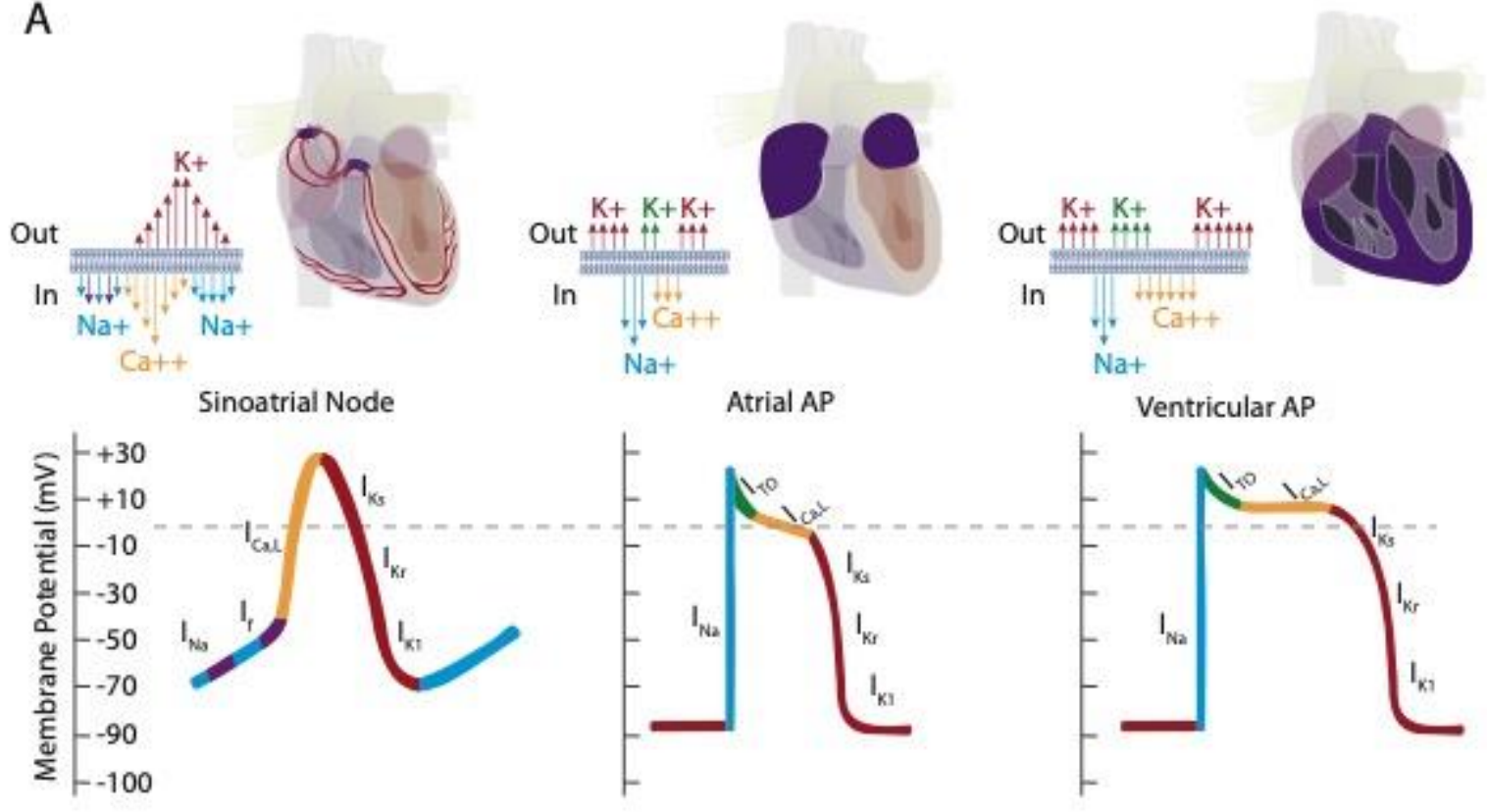

B
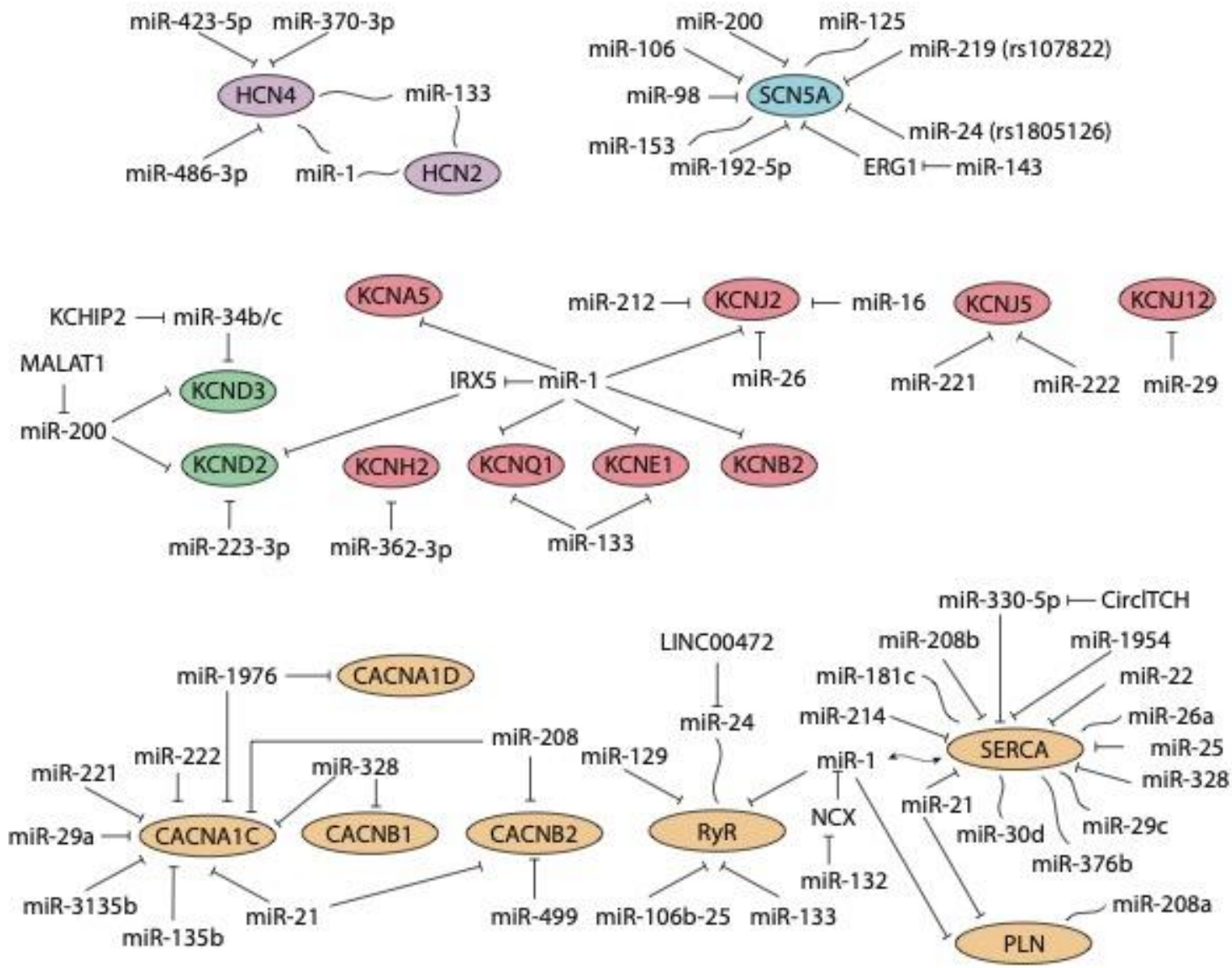

Figure 1. (A) Graphical representation of the cardiac action potential in the sinoatrial node (and also the atrioventricular node) and in contractile working myocardium of the atrial and ventricular chambers. (B) Schematic representation of the functional roles ncRNAs within the cardiac action potential regulation ( - direct; $\sim$ indirect). Colors represent different phases of the cardiac action potential and related genes. 
While emerging evidence is progressively increasing on the functional role of microRNAs on the regulation of SCN5A/Nav 1.5 , to date no information is available upon their putative contribution to sodium channel ancillary subunits in the cardiovascular contexts, although some reports for miR-449a, miR-34a, miR-133b, miR-143-3p, and miR1-3p modulating SCN2B $/ \mathrm{Na}_{V} \beta 2$ [54-57], miR-375 modulating SCN3B/ $\mathrm{Na}_{V} \beta 3$ [58], and miR-3175 and miR-424-5p modulating SCN4B/Nav $\beta 4[59,60]$ have been described in other biological contexts.

Similarly, the impact of microRNAs in the slow component of the $\mathrm{I}_{\mathrm{Na}}$ current, governed by SCN10A pore-forming channel has not been reported in the cardiovascular context, although some evidences have been reported in other biological contexts such as pain development [61,62]. A summary of the microRNA interaction with the sodium channels is provided on Table 1, while their links to distinct cardiac diseases is provided on Table 2.

Table 1. List of microRNAs reported to modulate ion channel expression in the heart.

\begin{tabular}{|c|c|c|c|c|}
\hline Current & microRNA & Gene & Function & Reference \\
\hline \multirow{5}{*}{$\mathbf{I}_{\mathrm{Na}}$} & miR-98, miR-106, miR-200, miR-219, miR-125, miR-153 & \multirow{5}{*}{ SCN5A } & $\mathrm{INa} \uparrow / \mathrm{INa} \downarrow$ & {$[47,53]$} \\
\hline & miR-192-5p & & $\mathrm{INa} \downarrow$ & [48] \\
\hline & miR-200c & & - & [50] \\
\hline & miR-143 & & $\mathrm{INa} \downarrow$ & [51] \\
\hline & miR-24 & & $\mathrm{INa} \downarrow$ & [52] \\
\hline \multirow{5}{*}{ If } & miR-423-5p & \multirow{4}{*}{$\mathrm{HCN} 4$} & If $\downarrow$ & [63] \\
\hline & miR-370-3p & & If $\downarrow$ & [64] \\
\hline & miR-486-3p & & If $\downarrow$ & [65] \\
\hline & miR-1, miR-133 & & If $\uparrow$ & [66-69] \\
\hline & miR-1, miR-133 & HCN2 & If $\uparrow$ & [66-69] \\
\hline \multirow{5}{*}{$\mathbf{I}_{\mathrm{TO}}$} & miR-1 & \multirow{4}{*}{ KCND2 } & $\mathrm{ITO} \downarrow$ & [70] \\
\hline & miR-223-3p & & $\mathrm{ITO} \downarrow$ & [71] \\
\hline & $\mathrm{miR}-34 \mathrm{~b} / \mathrm{c}$ & & $\mathrm{ITO}=$ & [72] \\
\hline & $\mathrm{miR}-200$ & & $\mathrm{ITO} \downarrow$ & [73] \\
\hline & miR-200 & KCND3 & $\mathrm{I}_{\mathrm{TO}} \downarrow$ & [73] \\
\hline $\mathbf{I}_{\text {Kur }}$ & miR-1 & KCNA5 & $\mathrm{I}_{\mathrm{Kur}} ?$ & [74] \\
\hline $\mathbf{I}_{\mathrm{Kr}}$ & miR-134, miR-103a-1, miR-143, miR-3619 & hERG & $\mathrm{I}_{\mathrm{Kr}} \downarrow$ & [75] \\
\hline \multirow{3}{*}{$\mathbf{I}_{\mathrm{KS}}$} & miR-1, miR-133 & KCNE1 & $\mathrm{I}_{\mathrm{KS}} \downarrow$ & {$[76,77]$} \\
\hline & miR-1, miR-133 & KCNQ1 & $\mathrm{I}_{\mathrm{KS}} \downarrow$ & [76] \\
\hline & miR-1, miR-133 & KCNB2 & $\mathrm{I}_{\mathrm{KS}} \downarrow$ & [77] \\
\hline \multirow{6}{*}{$\mathbf{I}_{\mathbf{K} 1}$} & miR-1 & \multirow{4}{*}{ KCNJ2 } & $\mathrm{IK} 1 \downarrow / \mathrm{IK} 1 \uparrow$ & {$[49,78,79]$} \\
\hline & miR-16 & & IK1 $1 \downarrow$ & [80] \\
\hline & miR-26 & & $\mathrm{IK} 1 \uparrow$ & {$[81,82]$} \\
\hline & miR-212 & & IK1 $\downarrow$ & {$[83,84]$} \\
\hline & miR-29 & KCNJ12 & $\mathrm{I}_{\mathrm{K} 1} \downarrow$ & [85] \\
\hline & $\mathrm{miR}-221 / 222$ & KCNJ5 & $\mathrm{I}_{\mathrm{K} 1 \downarrow} \downarrow$ & [86] \\
\hline
\end{tabular}


Table 1. Cont.

\begin{tabular}{|c|c|c|c|c|}
\hline Current & microRNA & Gene & Function & Reference \\
\hline \multirow{8}{*}{$\mathrm{I}_{\mathrm{Ca}, \mathrm{L}}$} & miR-328 & \multirow{6}{*}{ CACNA1C } & $\mathrm{I}_{\mathrm{Ca}, \mathrm{L}} \downarrow$ & [87] \\
\hline & miR-21, miR-208b & & $\mathrm{ICa}, \mathrm{L} \downarrow$ & {$[88,89]$} \\
\hline & miR-20a, miR-3135b & & $\mathrm{ICa}, \mathrm{L} \downarrow$ & [90] \\
\hline & miR-499 & & $\mathrm{ICa}, \mathrm{L} \downarrow$ & [91] \\
\hline & $\operatorname{miR}-135 b$ & & $\mathrm{ICa}, \mathrm{L} \downarrow$ & [92] \\
\hline & $\operatorname{miR}-221 / 222$ & & $\mathrm{ICa}, \mathrm{L} \downarrow$ & [86] \\
\hline & $\operatorname{miR}-328$ & CACNB1 & $\mathrm{ICa}, \mathrm{L} \downarrow$ & [87] \\
\hline & $\begin{array}{c}\text { miR-21, miR-208b } \\
\text { miR-499 } \\
\text { miR-329 }\end{array}$ & CACNB2 & $\begin{array}{l}\mathrm{ICa}, \mathrm{L} \downarrow \\
\mathrm{ICa}, \mathrm{L} \downarrow \\
\mathrm{ICa}, \mathrm{L} \downarrow\end{array}$ & $\begin{array}{c}{[88,89]} \\
{[91]} \\
{[91]} \\
\end{array}$ \\
\hline \multirow{17}{*}{ CICR } & miR-106b & \multirow{4}{*}{ RYR2 } & \multirow{4}{*}{-} & {$[93,94]$} \\
\hline & miR-129 & & & [95] \\
\hline & miR-1, miR-133 & & & {$[96,97]$} \\
\hline & miR-23 & & & {$[98,99]$} \\
\hline & miR-25 & \multirow{9}{*}{ SERCA2A } & \multirow{9}{*}{-} & {$[100,101]$} \\
\hline & $\operatorname{miR}-328$ & & & {$[102,103]$} \\
\hline & $\operatorname{miR}-29 c$ & & & [104] \\
\hline & miR-21 & & & [105] \\
\hline & miR-208b & & & [89] \\
\hline & $\operatorname{miR}-22$ & & & [106] \\
\hline & $\operatorname{miR}-214$ & & & [107] \\
\hline & miR-1954 & & & [108] \\
\hline & miR-376b, miR-1, miR-26a, miR-30d, miR-181 & & & [109] \\
\hline & $\operatorname{miR}-1, \operatorname{miR}-21$ & \multirow{2}{*}{ PLN } & \multirow{2}{*}{-} & [110] \\
\hline & miR-208a & & & [111] \\
\hline & miR-132 & \multirow{2}{*}{ NCX1 } & \multirow{2}{*}{-} & [112] \\
\hline & miR-1 & & & [107] \\
\hline
\end{tabular}

Table 2. List of genes involved in the cardiac action potential, their link to cardiovascular physiopathological conditions and their functional alterations in relation to distinct microRNAs signatures observed therein.

\begin{tabular}{|c|c|c|c|c|}
\hline Gene & Disease & Alteration & Mir Related & Reference \\
\hline \multirow{5}{*}{ SCN5A } & $\begin{array}{l}\text { Inherited arrhythmias and } \\
\text { cardiomyopathy }\end{array}$ & Mutation & - & [35-38] \\
\hline & Sudden death & SNPs & - & {$[39,40]$} \\
\hline & Brugada syndrome & SNPs $/ \downarrow$ expression & miR-219 & {$[47,53]$} \\
\hline & Atrial fibrillation & $\downarrow$ expression & miR-192-5p & [48] \\
\hline & Heart failure & SNPs $/ \downarrow$ expression & miR-24 & [52] \\
\hline \multirow{3}{*}{ SCN10A } & Sudden death & \multirow{3}{*}{ Mutation } & - & [41] \\
\hline & Atrial fibrillation & & - & {$[42,43]$} \\
\hline & Brugada syndrome & & - & {$[29,44,45]$} \\
\hline
\end{tabular}


Table 2. Cont.

\begin{tabular}{|c|c|c|c|c|}
\hline Gene & Disease & Alteration & Mir Related & Reference \\
\hline \multirow{3}{*}{ HCN4 } & Bradycardia & $\downarrow$ expression & $\begin{array}{l}\text { miR-423-5p, } \\
\text { miR-370-3p }\end{array}$ & {$[63,64]$} \\
\hline & Age atrial fibrillation & $\uparrow$ expression & miR-1, miR-133 & [66] \\
\hline & Myocarial infarction & $\uparrow$ expression & miR-1, miR-133 & {$[67,68]$} \\
\hline \multirow{2}{*}{ HCN2 } & Age atrial fibrillation & $\uparrow$ expression & miR-1, miR-133 & [66] \\
\hline & Myocardial infarction & $\uparrow$ expression & miR-1, miR-133 & {$[67,68]$} \\
\hline \multirow{3}{*}{ KCND2 } & Sudden death & $\downarrow$ expression & miR-1 & [70] \\
\hline & Acute myocardial infarction & $\downarrow$ expression & miR-223-3p & {$[71]$} \\
\hline & Myocardial infarction & $\downarrow$ expression & miR-200c & [73] \\
\hline \multirow{2}{*}{$\mathrm{KCNH} 2$} & LQT syndrome (type 2) & Mutation & - & [113] \\
\hline & Heart failure & $\downarrow$ expression & $\operatorname{miR} 362-3 p$ & [114] \\
\hline
\end{tabular}

KCNE2

LQT syndrome (type 6)

LQT syndrome (type 1)

\begin{tabular}{cccc} 
LQT syndrome (type 1) & $\downarrow$ expression & - & [115-117] \\
\hline Atrial fibrillation & $\downarrow$ expression & miR-1 & [77]
\end{tabular}

KCNB2

\begin{tabular}{|c|c|c|c|c|}
\hline \multirow{3}{*}{ Atrial fibrillation } & Myocardial infarction & $\downarrow / \uparrow$ expression & miR-1, miR-16 & {$[78,81]$} \\
\hline & Atrial fibrillation & $\uparrow$ expression & miR-1, miR-26 & {$[49,79,82]$} \\
\hline & Heart failure & $\downarrow$ expression & $\operatorname{miR}-212$ & [84] \\
\hline KCNJ12 & Myocardial infarction & $\downarrow$ expression & miR-29 & [85] \\
\hline KCNJ5 & Atrial fibrillation & $\downarrow$ expression & $\mathrm{miR}-221 / 222$ & [86] \\
\hline \multirow{5}{*}{ CACNA1C } & \multirow{5}{*}{ Atrial fibrillation } & \multirow{5}{*}{$\downarrow$ expression } & $\mathrm{miR}-221 / 222$ & [86] \\
\hline & & & miR-328 & [87] \\
\hline & & & $\operatorname{miR}-21$ & {$[88]$} \\
\hline & & & miR-208b & [89] \\
\hline & & & $\begin{array}{l}\text { miR-29b, } \\
\text { miR-3135b }\end{array}$ & [90] \\
\hline \multirow{3}{*}{ CACNB2 } & \multirow{3}{*}{ Atrial fibrillation } & \multirow{3}{*}{$\downarrow$ expression } & miR-21 & [88] \\
\hline & & & miR-208b & [89] \\
\hline & & & miR-499, miR-329 & [91] \\
\hline \multirow{5}{*}{ RYR2 } & \multirow{5}{*}{ Atrial fibrillation } & \multirow{5}{*}{$\uparrow$ expression } & miR-106b-25 & {$[93,94]$} \\
\hline & & & miR-106a, miR-93 & {$[94,118]$} \\
\hline & & & $\operatorname{miR}-129^{*}$ & [95] \\
\hline & & & miR-1*, miR133* & {$[96,97]$} \\
\hline & & & $\operatorname{miR}-24^{*}$ & {$[98,99]$} \\
\hline
\end{tabular}


Table 2. Cont.

\begin{tabular}{|c|c|c|c|c|}
\hline Gene & Disease & Alteration & Mir Related & Reference \\
\hline \multirow{9}{*}{ SERCA2A } & \multirow{9}{*}{ Atrial fibrillation } & \multirow{9}{*}{$\downarrow$ expression } & $\operatorname{miR}-25$ & {$[100,101]$} \\
\hline & & & $\operatorname{miR}-328$ & {$[102,103]$} \\
\hline & & & $\operatorname{miR}-29 c$ & [104] \\
\hline & & & $\begin{array}{l}\operatorname{miR}-21^{*} \\
\operatorname{miR}-208 b^{*}\end{array}$ & {$[89,105]$} \\
\hline & & & $\begin{array}{l}\operatorname{miR}-214^{*} \\
\operatorname{miR}-1954^{*}\end{array}$ & {$[107,108]$} \\
\hline & & & miR-376b, miR-1*, & [109] \\
\hline & & & $\begin{array}{l}\text { miR-26a*, } \\
\text { miR-30d*, }\end{array}$ & [109] \\
\hline & & & $\operatorname{miR}-181 c^{*}$ & [109] \\
\hline & & & miR-330-5p* & [119] \\
\hline \multirow{2}{*}{ PLN } & \multirow{2}{*}{ Cardiac arrhythmias } & \multirow{2}{*}{ - } & miR-1, miR-21 & [98] \\
\hline & & & miR-208a* & [99] \\
\hline \multirow{2}{*}{ NCX1 } & \multirow{2}{*}{ Cardiac arrhythmias } & \multirow{2}{*}{-} & miR-132 & [112] \\
\hline & & & miR-1 & [107] \\
\hline
\end{tabular}

* indirect regulation.

\section{2. ncRNAs in the Upstroke Phase (If Current)}

The upstroke phase of the cardiac action potential in slow conducting cells, i.e., sinoatrial and atrioventricular nodal myocytes, is primarily modulated by the funny current, i.e., $\mathrm{I}_{\mathrm{f}}$ current. Almost 40 years ago, the 'funny' (pacemaker, $\mathrm{I}_{\mathrm{f}}$ ) current was firstly described in sinoatrial node (SAN) myocytes [120]. The hyperpolarization-activated cyclic nucleotide-gated $(\mathrm{HCN})$ channels are the structural pore-forming subunits governing this current, with four HCN isoforms known (HCN1-4), among which $\mathrm{HCN} 4$ is the most highly expressed in the sinoatrial and atrioventricular nodes (Figure 1A).

Current information regarding the functional role of ncRNAs, particularly microRNAs, is progressively emerging. D'Souza et al. [63] reported a direct biochemical interaction between miR-423-5p and HCN4 and they further demonstrated that miR-423-5p contributes to training-induced bradycardia by targeting HCN4. Thus miR-423-5p modulates the $\mathrm{I}_{\mathrm{f}}$ current and the heart rate in mice. Yanni et al. [64] reported direct interaction between miR-370-3p and HCN4 (Figure 1B). Gain-of-function experiments in vitro demonstrate its role provoking bradycardia and loss-of-function assays in vivo revealed that silencing miR-370-3p in a heart failure mouse model, increases HCN4 mRNA and protein expression, increasing therefore $\mathrm{I}_{\mathrm{f}}$ current in the sinus node and thus blunting sinus bradycardia. More recently, a microRNA array analysis in the human sinoatrial node vs. surrounding atrial tissue identified 18 upregulated and 48 downregulated microRNAs [65]. Among them, the authors demonstrate that miR-486-3p was directly targeting $\mathrm{HCN} 4$ and, if over-expressed in rat sinoatrial node preparations, cardiomyocyte beating was reduced by almost a third (Figure 1B). Thus, these data demonstrate that several microRNAs can influence HCN4 expression and thus $\mathrm{I}_{\mathrm{f}}$ current, impacting therefore in heart rate control.

Indirect evidence on the role of miR-1 and miR-133 regulating HCN isoforms have been also reported. Inversed expression patterns of HCN2 and HCN4 (upregulated) and miR-1 and miR-133 (downregulated) have been reported in age-associated atrial fibrillation [66] myocardial infarction (MI) [67,68], and exercise training [69], yet it remains to be established if these microRNAs can direct target $\mathrm{HCN}$ isoforms (Figure 1B).

No information is currently available about the plausible regulatory effects of microRNAs in HCN1 and HCN3 in the cardiovascular system, although in other biological 
contexts, such as in the brain, it has been identified that miR-706 targets HCN1 [121]. Similarly, no evidence has been reported to date on the direct functional role of microRNAs regulating HCN4 in arrhythmogenic syndromes, supporting the notion that additional studies are required in this context. A summary of the microRNA interaction with the HCN channels is provided on Table 1, while their links to distinct cardiac diseases is provided on Table 2.

\section{3. ncRNAs in Sodium Channel Interacting Proteins}

It has been recently reported that $\mathrm{Na}_{\mathrm{V}} 1.5$ may be part of multi-protein complexes composed of $\mathrm{Na}_{\mathrm{V}} 1.5$-interacting proteins which regulate channel expression and function [122,123]. These $\mathrm{Na}_{\mathrm{V}} 1.5$ interacting proteins can be classified as anchoring/adaptor proteins, enzymes interacting with and modifying the channel, and proteins that modulate $\mathrm{Na}_{\mathrm{V}} 1.5$ biophysical upon binding. Importantly, mutations in several of genes encoding these regulatory proteins have also formed in patients with cardiac arrhythmias [124-127]. To date, at least 17 different interacting proteins have been described [123], among which only a small subset of them have been reported to be modulated by microRNAs-i.e., calmodulin, caveolin, and Nedd4 ubiquitin ligases-as detailed below.

Calmodulin has been extensively reported to directly interact with $\mathrm{Na}_{\mathrm{V}} 1.5$ (SCN5A) sodium channel and thus to modulate its function [128-135]. Although distinct microRNAs such as miR-1 [136], let-7a [137], miR-625-5p [138], miR-525-5p [139], miR-338-5p [140], miR-185 [141], miR-145 [142], miR-30b-5p [143], and miR-675 [144] have been reported to modulate calmodulin expression, these reports exclusively describe their functional role in cardiac hypertrophy and failed to provide a direct link to sodium channel regulation. To date, the only report linking microRNAs, i.e., miR-26a, and cardiac arrhythmias, i.e., atrial fibrillation, is reported by Qi et al. [145]. Thus, the plausible contribution to sodium channel function by calmodulin interactive protein remains elusive.

Caveolin has been recently linked to $\mathrm{Na}_{\mathrm{V}} 1.5$ function $[146,147]$. To date, only miR-22 have been reported to target caveolin-3 in the cardiovascular setting. Similarly, as for microRNAs-calmodulin interactions, the implications for sodium channel function or for cardiac electrophysiology at large have not been reported [148,149].

Nedd 4 ubiquitin ligases role in $\mathrm{Na}_{\mathrm{v}} 1.5$ have also been reported [150-152]. miR-1 targets Nedd4 in Drosophila and Nedd4l in mammals, supporting a plausible role modulated trafficking or degrading Need4/Need4l substrates in the heart—such as Scn5a [153]—yet direct evidence remains to be elucidated.

\section{Role of ncRNAs in Cardiac Repolarization}

Cardiac repolarization can be divided into different phases, starting with a rapid repolarization phase, followed by a plateau phase and ending with the terminal phase by which the resting membrane potential is reestablished. The rapid repolarization is mainly controlled by the rapidly activating transient outward $\left(\mathrm{I}_{\mathrm{TO}}\right)$. The plateau phase contains the contribution of the rapid $\left(\mathrm{I}_{\mathrm{Kr}}\right)$ and slow $\left(\mathrm{I}_{\mathrm{Ks}}\right)$ delayed rectifier $\mathrm{K}+$ currents, as well as the ultra-rapid delayed rectifier $\left(\mathrm{I}_{\mathrm{Kur}}\right)$ currents, which are counterbalanced by the depolarization contribution of L-type calcium current $\left(\mathrm{I}_{\mathrm{Ca}}\right)$. Finally, $\mathrm{I}_{\mathrm{Kr}}$ and the inward rectifier $\mathrm{K}+$ current $\left(\mathrm{I}_{\mathrm{K} 1}\right)$ contribute with repolarizing currents at the terminal phase of the action potential, reestablishing the resting membrane potential [154] (Figure 1A).

\section{1. ncRNAs in the Early Repolarization (I $I_{T O}$ Transient Outward K+ Current)}

After cardiac depolarization, the early repolarization process is governed by cardiac transient outward potassium current $\left(\mathrm{I}_{\mathrm{TO}}\right)$. $\mathrm{I}_{\mathrm{TO}}$ is rapidly activated after a fast increase of the membrane potential, where a short-lived, hyperpolarizing outward $\mathrm{K}+$ current $\left(\mathrm{I}_{\mathrm{TO}}\right)$ makes $\mathrm{K}+$ ions from inside the cells to flow to the extracellular space, causing the transmembrane voltage to decrease. $\mathrm{I}_{\mathrm{TO}}$ is then quickly deactivated, stopping the repolarization and ending the first phase of the action potential [155]. $\mathrm{I}_{\mathrm{TO}}$ has two components, i.e., fast $\left(\mathrm{I}_{\mathrm{TOf}}\right)$ and slow ( $\mathrm{I}_{\mathrm{TOf}}$ ) components. $\mathrm{I}_{\mathrm{TOf}}$ is the principal subtype present in human atria while both 
$\mathrm{I}_{\mathrm{TOf}}$ and $\mathrm{I}_{\mathrm{TOs}}$ are present in the ventricles [156]. The channel leading to $\mathrm{I}_{\mathrm{TOf}}$ current is formed by assembly of $\mathrm{K}_{\mathrm{v}} 4.2(K C N D 2)$ or $\mathrm{K}_{\mathrm{v}} 4.3(K C N D 3)$ subunits or a combination of both, while $\mathrm{I}_{\mathrm{TO}}$ current channel is formed by $\mathrm{K}_{\mathrm{v}} 1.4$ (KCNA4) subunits [155].

Several microRNAs have been described to be involved in the regulation of these channels. In particular, in 2007, Zhao and co-workers [70], demonstrated that Kcnd2 is positively regulated by miR-1, through Ir $x 5$ inhibition in mice, thus altering the endocardial to epicardial transmural gradient controlled by Kcnd 2 within the ventricular cardiomyocytes and thus resulting in ventricular repolarization abnormalities. Kcnd2 is also regulated by miR-223-3p, a microRNA that is remarkably upregulated in a rat model of acute MI and consequently, $\mathrm{K}_{\mathrm{v}} 4.2$ protein levels and $\mathrm{I}_{\mathrm{TO}}$ density were significantly decreased [71] (Figure 1B). Such impaired modulation of $\mathrm{K}_{\mathrm{v}} 4.2$ protein expression and thus of $\mathrm{I}_{\mathrm{TO}}$ current can cause prolongation of the action potential duration and thus promote arrhythmias.

Several evidences have demonstrated that KChip2 associates with and modulates the Kv4 family of potassium channels [157,158]. Importantly, KChip2 protein negatively modulates miR-34b/c expression that in turn targets $\mathrm{Kv} 4.3$, modulating $\mathrm{I}_{\mathrm{TO}}$ current. Importantly Kv4.2 and Kv1.4 are not regulated by miR-34, thus modulation of $\mathrm{I}_{\mathrm{TO}}$ current is only observed on this fast $\left(\mathrm{I}_{\mathrm{TO}, \mathrm{f}}\right)$, but not on the slow $\left(\mathrm{I}_{\mathrm{TO}, \mathrm{s}}\right)$ component. Beside regulating $\mathrm{I}_{\mathrm{TO}, \mathrm{f}}, \mathrm{miR}-34$ it also modulates $S c n 5 a$ and $S c n 1 b$ expression and thus $\mathrm{I}_{\mathrm{Na}}$ current [150]. Thus these data identified KChip2/miR-34 axis as a core regulator of electrical dysfunction, suggesting miR-34 as a therapeutic target for treating arrhythmogenesis in heart disease [72] (Figure 1B).

In addition to the functional role of microRNAs modulating $\mathrm{I}_{\mathrm{TO}}$ current, it has been recently elucidated the possible relation between lncRNAs and $\mathrm{I}_{\mathrm{TO}}$ currents. In particular, MALAT1 mediates cardiac $\mathrm{I}_{\mathrm{TO}}$ current regulating miR-200c/HMGB1 pathway that controls KCND2 and KCND3 expression [73] in a rat experimental model of MI (Figure 1B). Furthermore, MALAT1 knockdown improved several cardiac electrophysiological parameters, particularly $\mathrm{I}_{\mathrm{TO}}$ current, in post-MI cardiomyocytes and thus provides evidence that it might represent a novel potential therapeutic target for MI.

\section{2. ncRNAs in the Plateau Phase and Terminal Repolarization ( $I_{K r}, I_{K s}, I_{K u r} K+$ Current)}

Rapid repolarization is followed by a plateau phase, a phase that is characterized by almost equal flow of outward $\mathrm{K}^{+}$currents, i.e., through delayed rectifier $\mathrm{K}^{+}$channels $\left(\mathrm{I}_{\mathrm{Kr}}\right.$, $\left.\mathrm{I}_{\mathrm{Ks}}, \mathrm{I}_{\mathrm{Kur}}\right)$ and inward $\mathrm{Ca}^{2+}$ current regulated by L-type $\mathrm{Ca}^{2+}$ channels $\left(\mathrm{I}_{\mathrm{CaL}}\right)$.

\section{3. ncRNAs Modulating the Ultra-Rapid Delayed Rectifier K+ Current $\left(I_{K u r}\right)$}

$\mathrm{I}_{\mathrm{Kur}}$ currents have been recently identified to be modulated by $\mathrm{K}_{\mathrm{v}} 1.5$ alpha pore forming subunits, encoded by KCNA5. $\mathrm{I}_{\mathrm{Kur}}$ currents are a major contributor to atrial repolarization $[159,160]$. Biochemical interaction between miR-1 and human KCNA5 3'UTR has been recently validated [74] yet in vivo functional consequences of miR-1/KCNA5 interactions has only been demonstrated in rat pulmonary hypertension [74] (Figure 1B). Therefore, it remains unclear the contribution ncRNAs regulating $\mathrm{I}_{\mathrm{Kur}}$ in the context cardiac electrophysiology.

\section{4. ncRNAs Modulating the Rapid Delayed Rectifier K+ Current $\left(I_{K r}\right)$}

$\mathrm{I}_{\mathrm{Kr}}$ currents are governed by hERG channels, also known as $\mathrm{K}_{\mathrm{v}} 11.1$ [161]. As an homolog of the Drosophila "ether-a-go-go" (EAG) potassium channel, hERG was first cloned in the brain [162]. hERG channels are encoded by KCNH2 and mutations in KCNH2 have been associated to long QT syndrome (type 2; LQTS2) [113]. Ancillary MiRP1 (or KCNE2) subunits, that constitute single transmembrane protein homologous to KCNE1, was shown to associate with HERG channels and modulate $I_{K r}$ biophysical properties [163]. Mutations in KCNE2 have also been associated to long QT syndrome (type 6; LQTS6) [163].

Mourad [114] has shown that miR-362-3p was significantly higher in the heart failure with reduced ejection fraction (HFrEF) group compared to controls whereas hERG expression was significantly lower in the HFrEF group compared to controls [114] (Figure 1B). 
However, direct biochemical interaction evidence between miR-362-3p and hERG have not been reported. Growing evidence is showing that microRNAs are involved in functional modulation of the hERG/KCNH2 pathway. In particular, miR-134, miR-103a-1, miR-143, and miR-3619 significantly suppressed hERG mRNA expression in U2OS cells [75]. Furthermore, these authors demonstrated that miR-103a- 1 decreased the $\mathrm{I}_{\mathrm{Kr}}$ activation current and $\mathrm{I}_{\mathrm{Kr}}$ tail current amplitude of hERG channel, and also is accelerated the hERG protein channel inactivation process [75] in HEK293T cells, yet direct evidence in cardiomyocytes remains elusive. Other two microRNAs have been demonstrated to regulate hERG expression in pathological contexts, i.e., cancer. MiR-328 [164] and miR-362-3p [165] reduced hERG-related current and inhibited breast cancer cell proliferation. In summary, scarce information is currently available on the functional role of ncRNAs regulating $\mathrm{I}_{\mathrm{Kr}}$ current in the cardiovascular setting.

\section{5. $n c R N A s$ Modulating the Slow Delayed Rectifier $K+$ Current $\left(I_{K s}\right)$}

$\mathrm{I}_{\mathrm{Ks}}$ channels are slowly activated during the plateau phase by depolarizing voltages. The pore-forming subunit KCNQ1 (KvLQT1 or $\mathrm{K}_{\mathrm{v}} 7.1$ ) was first identified by positional cloning and linked to long QT syndrome (type 1; LQT1) [166]. Importantly, KCNE1, also known as Mink [115], represent the ancillary subunit that when co-assembles with KCNQ1 provides to this channel its unique slow kinetics similar to that of the native $\mathrm{I}_{\mathrm{Ks}}$ current in cardiomyocytes [116,117]. In addition, KCNB2, that is weakly expressed in the heart [117] as compared to other tissues, have been reported to affect cardiac $\mathrm{K}+$ currents, playing a pivotal role in cell excitability [167].

To date, scarce evidence is available regarding the functional impact of ncRNAs in $\mathrm{I}_{\mathrm{Ks}}$ current modulation. Li et al. [76] examine miR-1/miR-133 levels, the potassium channel KCNE1 and KCNQ1 levels and $\mathrm{I}_{\mathrm{Ks}}$ current in cardiac progenitor cells (CPCs) of normal human hearts. These authors observed that human CPCs expressed KCNE1 and KCNQ1 and possessed functional $\mathrm{I}_{\mathrm{Ks}}$ currents (Figure 1B). Moreover, high-level glucose exposure in human CPCs lead to augmented miR-1 and miR-133 expression and concomitant decreased KCNE1 and KCNQ1 expression, and thus $\mathrm{I}_{\mathrm{Ks}}$ reduction. These data support a role for $\mathrm{miR}-1 / \mathrm{miR}-133$ in $\mathrm{I}_{\mathrm{Ks}}$ regulation (Figure 1B); however, their functional roles in native and mature cardiomyocytes remains undetermined. Although the functional effects of KCNB2 on the cardiovascular system have been scarcely explored, it has been demonstrated that miR-1 modulates KCNB2. In vivo experiments found that the upregulation of miR-1 reduced in KCNE1 and KCNB2 expression, shortened the atrial effective refractory period (AERP) of the right atrium and enhanced the inducibility of AF [77] (Figure 1B).

\section{6. $n c R N A$ s in the Resting Membrane Potential ( $I_{K 1}$ Current and Na,K ATPase)}

Terminal repolarization is increased after the plateau phase a process mainly governed by the rapid delayed rectifier current $\left(\mathrm{I}_{\mathrm{Kr}}\right)$ and the inward rectifier $\mathrm{K}^{+}$current $\left(\mathrm{I}_{\mathrm{K} 1}\right)[168,169]$. $\mathrm{I}_{\mathrm{K} 1}$ stabilizes the resting membrane potential and is responsible for shaping the initial depolarization and final repolarization of the cardiac action potential. The Kir2 subfamily members, Kir2.1, Kir2.2, Kir2.3, and Kir2.4 contribute to the cardiac $\mathrm{I}_{\mathrm{K} 1}$ current [170] and they are encoded by KCNJ2, KCNJ12, KCNJ4, and KCNJ14, respectively.

Several microRNAs have been reported to modulate $\mathrm{I}_{\mathrm{K} 1}$ current in distinct biological contexts. miR-1 levels are increased in patients with coronary artery diseases (CAD) and also in an experimental rat model of MI. In this context, miR-1 silences KCNJ2 protein expression, and also GJA1, by directly targeting their 3'UTRs, respectively [78] (Figure 1B). On the contrary hand, miR-1 levels are greatly reduced in human AF as well as in AF experimental models, contributing to upregulation of Kir2.1 subunit, leading thus to increased $\mathrm{I}_{\mathrm{K} 1}$, being this upregulation of inward-rectifier currents important for AF maintenance [49,79]. Additionally, miR-16 overexpression suppress KCNJ2/Kir2.1 expression in a rat experimental model of MI [80]. Further in vivo experimental analysis also demonstrates that valsartan, an angiotensin II inhibitor, can decrease miR-16, and thus increase KCNJ2/Kir2.1, expression, while angiotensin II administration provoked the opposite effects [80]. miR-26 have 
been reported to be downregulated in AF patients. Experimental over-expression studies in mice demonstrated that miR-26 can modulates KCNJ2/Kir2.1 expression. Furthermore, miR-26 endogenous knockdown in mice promoted AF while ectopic expression reduced $\mathrm{AF}$ vulnerability, demonstrating an essential role for miR-26 regulating $\mathrm{I}_{\mathrm{K} 1}$ current and thus $\mathrm{AF}$ onset $[81,82]$ (Figure 1B). Finally, miR-212, one of the most upregulated miRNAs in human heart failure [83], also targets $\mathrm{KCNJ} 2$, severely downregulating $\mathrm{I}_{\mathrm{K} 1}$ current and thus contributing to the risk of cardiac arrhythmia during the process of myocardial remodeling en route to heart failure [84] (Figure 1B). In addition to the regulation of KCNJ2 by microRNAs, KCNJ12 has been reported to be regulated by miR-29 [85] as well as KCNIP2 (Figure 1B). miR-29 expression levels are significantly increased in the ischemic region of MI mouse hearts and both KCNJ12 and KCNIP2 protein/mRNA expression levels were significantly decreased [85]. Thus, modulation of miR-29 expression is highly relevant given its role controlling the cardiac membrane resting potential, thought $\mathrm{I}_{\mathrm{K} 1}$ current regulation, and thus represents a plausible therapeutic target against ischemic arrhythmias. Recently, it has been evidenced that miR-221 and miR-222 target KCNJ5 and, therefore, potentially contribute to disturbed cardiac excitation generation and propagation [86] (Figure 1B). A summary of the microRNA interaction with the potassium channels is provided on Table 1, while their links to distinct cardiac diseases is provided on Table 2.

The resting membrane potential of the cardiac action potential, beside the contribution of IK1 current, is also modulated by the Na,K-ATPase. Na,K-ATPase is composed of four distinct alpha (ATP1A1 to ATP1A4) and beta (ATP1B1 to ATP1B4) subunits and it regulates sodium export and potassium import across the plasma membrane in a large variety of cells. Within the heart, the most prominently expressed $\mathrm{Na}$,K-ATPase alpha subunits are ATP1A1, ATP1A2, and ATP1A3 [171-178] and ATP1B1 and ATP1B2 as Na,K-ATPase beta subunits [171-174,177,179-181]s. Our current understanding of the functional role of ncRNAs in Na,K-ATPase biology is scarce. Drummond et al. [182,183] demonstrate that impairment signaling of $\mathrm{Na}, \mathrm{K}-\mathrm{ATP}$ ase leads to upregulation of miR-29b-3p in the heart of a model of chronic kidney disease, a process that is modulated by the upregulation of this microRNA in cardiac fibroblasts. Besides this study, no additional evidence has been reported to date about the contribution of microRNAs and/or lncRNAs regulating $\mathrm{Na}, \mathrm{K}-\mathrm{ATPase}$ expression and/or function in the cardiovascular system.

\section{Role of ncRNAs in Conduction Contraction Coupling}

\section{1. ncRNAs in Calcium Currents ( $I_{C a, L}$ Current)}

$\mathrm{Ca}^{2+}$ ions play a pivotal role in the excitation and contraction of the heart. $\mathrm{Ca}^{2+}$ influx within ventricular myocytes occurs through voltage-activated $\mathrm{Ca}^{2+}$ channels, contributing to the plateau phase of the cardiac action potential. L-type $\mathrm{Ca}^{2+}$ channels are considered the most important contributors to the $\mathrm{Ca}^{2+}$ influx in the working myocardium (Figure 1A). There are four members on the L-type $\mathrm{Ca}^{2+}$ channels family, namely $\mathrm{Ca}_{\mathrm{v}} 1.1$ to $\mathrm{Ca}_{\mathrm{v}} 1.4$. L-type calcium channels $\left(\mathrm{Ca}_{v} 1\right)$ represent one of the three major classes $\left(\mathrm{Ca}_{\mathrm{v}} 1-3\right)$ of voltagegated calcium channels.

Transgenic mice overexpressing miR-1 resulted in severe electrophysiological defects, causing atrioventricular block [184]. Molecular analysis demonstrates that several key components contributing to the electrical wiring of the heart were altered, such as $\mathrm{C} \times 43$ and Kir2.1. Electrophysiological studies revealed that $\mathrm{I}_{\mathrm{Ca}}$ and $\mathrm{I}_{\mathrm{K} 1}$ currents were decreased. Knockdown of miR-1 overexpression using LNA-anti-miR-1 administration reversed such electrophysiological alteration, demonstrating a pivotal role for miR-1 in cardiac electrophysiology and particularly in calcium homeostasis. More recently, Zhang et al. (2019) demonstrated that transgenic mice overexpressing miR-1976 directly targeted two key calcium channels (i.e., Cav1.2 and Cav1.3, encoded by CACNA1C and CACNA1D, respectively) resulting in SAN dysfunction and thus lower heart rates, a phenotype reminiscent of sick sinus node syndrome in humans [185].

In 2010, Lu et al. [87] demonstrated that miR-328 targets L-type $\mathrm{Ca}^{2+}$ channel genesi.e., $\mathrm{CACNA} 1 \mathrm{C}$ and $\mathrm{CACNB1}$-contributing to the adverse atrial electric remodeling in $\mathrm{AF}$ 
(Figure 1B). Using an experimental canine model atrial tachypacing, these authors demonstrated that miR-223, miR-328, and miR-664 were upregulated whereas miR-101, miR-133, miR-145, miR-320, miR-373, and miR-499 were downregulated. miR-328 upregulation was subsequently validated in atrial tissues from AF patients. Forced expression of miR-328 increased the vulnerability of dogs to electrical AF induction while miR-328 transgenic mice developed AF. Electrophysiological analysis demonstrated that $\mathrm{I}_{\mathrm{Ca}}$ was substantially decreased while $\mathrm{I}_{\mathrm{TO}}, \mathrm{I}_{\mathrm{Kur}}$ and $\mathrm{I}_{\mathrm{K} 1}$ currents were unaltered. During chronic human AF, miR-21 and miR-208b expression levels are increased, promoting a decrease of $\mathrm{I}_{\mathrm{Ca}, \mathrm{L}}$ density by downregulating $\mathrm{Ca}^{2+}$ channels subunits expression, particularly, CACNA1C and CACNB2 [88,89] (Figure 1B). Therefore miR-21 and miR-328 leads to $\mathrm{I}_{\mathrm{Ca}, \mathrm{L}}$ downregulation and thus to shortening in the cardiac action potential that might be responsible to selfperpetuate AF. In addition, $\mathrm{miR}-29 \mathrm{a}$ and miR-3135b have been shown to be differentially expressed in AF, and both microRNAs directly target CACNA1C [90]. miR-29a overexpression assays in atrial myocytes further demonstrated a significant reduction on $\mathrm{I}_{\mathrm{Ca}, \mathrm{L}}$ current density. However, the functional roles of these microRNAs in vivo remains to be determined. Similarly, increased miR-499 have been reported in permanent AF patients and forced expression of miR-499 induces the downregulation of CACNB2 expression in HL1 atrial cardiomyocytes, resulting also into downregulation of the pore forming alpha subunit CACNA1C protein levels. Furthermore, these authors demonstrated that miR-329 is a direct target of CACNB2 and thus provide circumstantial evidence that miR-329 may contribute to the electrical remodeling in AF [91], yet in vivo experiments are required to fully validate such a hypothesis (Figure 1B).

Moreover, L-type calcium channels play important role in cardiac hypertrophy. Recent studies in mice revealed that miR135b is significantly diminished in cardiac hypertrophy. Interestingly, miR-135b overexpression attenuated cardiac hypertrophy by directly targeting CACNA1C (Figure 1B), reducing $\mathrm{I}_{\mathrm{Ca}}$ density and shortening the cardiac action potential duration [92]. miR-221/222 expression levels have been analyzed in a mouse model of severe cardiac hypertrophy that also displayed electrophysiological alterations in absence of fibrosis. Both microRNAs were increased in cardiomyocytes but not in cardiac fibroblasts. miR-221 and miR-222 contributed to L-type $\mathrm{Ca}^{2+}$ channels regulation by directly targeting CACNA1C leading to reduced $\mathrm{I}_{\mathrm{Ca}}$ density [86] (Figure 1B). Curiously, miR-221 also directly targeted Kcnj5 while miR-22 targeted Kcnj5, Cacna2b, and Kcnd2, yet the functional consequences on their corresponding ion channels remains to be determined. Recently, Liu et al. [93,186], demonstrated that miR-145 effectively alleviates heart failure related cardiac remodeling by improving cardiac dilation, fibrosis, intracellular $\mathrm{Ca}^{2+}$ mishandling and electrophysiological instability in a myocardial infarct mouse model. Particularly, these authors demonstrated that miR-145 is significantly reduced in an experimental rat model of heart failure, and miR-145 overexpression reversed heart failure-induced $\mathrm{I}_{\mathrm{Ca}}$ density reduction, intracellular $\mathrm{Ca}^{2+}$ homeostasis as well as the prolongation of the QTc interval. Whereas evidence on the modulatory role of microRNAs in calcium channel expression is still incipient, these data suggest that targeting discrete microRNAs might represent a novel strategy to attenuate cardiac hypertrophy. A summary of the microRNA interactions with the calcium channels is provided on Table 1, while their links to distinct cardiac diseases is provided on Table 2 .

\subsection{The Role of ncRNAs in Calcium-Induced Calcium Release}

Calcium induced calcium release (CICR) represents the mechanism by which cardiomyocytes can couple conduction and contraction. $\mathrm{Ca}^{2+}$ enter the cells through the L-type calcium channels as previously detailed, increasing intracellular $\mathrm{Ca}^{2+}$ that leads to massive delivery of $\mathrm{Ca}^{2+}$ from the sarcoplasmic reticulum (SR) by the ryanodine receptor (Ryr2). $\mathrm{Ca}^{2+}$ is then coupled to troponin, promoting contraction, and is subsequently released from the thin filaments, and re-stored into the SR by calcium ATPase SERCA2 while part of it is also exported outside the cells by the $\mathrm{Na}^{+}-\mathrm{Ca}^{2+}$ exchanger (NCX1). Importantly, phospholamban (Pln) regulated SERCA2 activity (Figure 1A). 
Multiple evidences have demonstrated the contribution of microRNAs to Ryr2 function by directly affecting Ryr2 expression such as miR-106b-25 [93,94]. In particular, miR106b-25 deficient mice displayed increased total Ryr2 protein expression in the atrial tissue, within normal subcellular distribution but $\mathrm{Ca}^{2+}$-spark frequency and total SR- $\mathrm{Ca}^{2+}$ leakage were increased [94]. Furthermore, miR106-25 null mice displayed atrial ectopy and were more susceptible to pace-induced AF [94]. Such effects are in part mediated by direct Ryr2 targeting by miR-106a, miR-106b, and miR-93 in mice [94]. Importantly, only a subset of AF patients displayed impaired miR-106-25 expression, while RYR2 was in all cases increased, supporting the notion that additional players contribute to AF development [118]. Ryr2 regulation by microRNAs has also been reported as indirect mechanisms such as for the case of miR-129 that regulates Grind2 and thus $\mathrm{Ca}^{2+}$ signaling [95] or by modulating Ryr2 phosphorylation such as miR-1 /miR-133 [96,97]. It has been demonstrated an enhanced excitation-contraction coupling in miR-133- [96] and miR-1 [97] -overexpressing myocytes, respectively, a process that stems from increased responsiveness of Ryr2 to triggering $\mathrm{Ca}^{2+}$. Importantly, that miR-133 and miR-1 can directly target the catalytic subunits of PP2A phosphatase, and since inhibition of phosphatase activity results in the enhanced propensity of ventricular myocytes toward the generation of $\mathrm{Ca}^{2+}$-dependent afterdepolarizations, these results indicate the involvement of muscle-specific miRNAs in the regulation of CaMKII-dependent phosphorylation of the Ryr2 via PP2A. Additional evidence of indirect modulation of Ryr2 function have been reported by Li et al. [98] by in vivo miR-24 inhibition in mice, resulting in restorage of the $\mathrm{Ca}^{2+}$ transient amplitude, and thus the excitation-contraction coupling impairment produced by transverse aortic constriction (TAC)-induced cardiac hypertrophy. However, the precise mechanisms as how miR-24 influences Ryr2 remains elusive. Similarly, LncRNA-LINC00472 modulation also regulates Ryr2 expression, since it acts as a miR-24 sponge, yet the precise mechanisms are unclear [99] (Figure 1B).

Similarly, increasing evidences have been reported on the functional contribution of microRNAs regulating SERCA2A/ATPa2a. miR-25 [100,101], miR-328 [102,103], and miR$29 \mathrm{c}$ [104] can directly regulate SERCA2A. By generating miR-25 sponges, it was reported that SERCA2a and PLN expression were increased but not Ncx, Ryr2 or Ip3r2, yet no calcium coupling electrophysiological measurements were provided [100]. Importantly, miR25 is upregulated in patients with severe heart failure, expressed in cardiomyocytes, and directly targets Serca2a, thus regulating $\mathrm{Ca}^{2+}$ kinetics in vitro [101]. Moreover, in vivo miR25 administration downregulated Serca2a and provokes a progressive decline in fractional shortening in mice while anti-miR-25 in vivo injections in an experimental mouse model of chronic pressure overload, substantially improving cardiac function [101]. SERCA2 has been reported to be direct target of miR-328 [102] and also to increase intracellular $\mathrm{Ca}^{2+}$ concentrations in H9c2 cardiomyocytes [103]. In addition, miR-29c have been reported to directly interact with SERCA by dual luciferase assays and thus to provoke protein downregulation and impaired $\mathrm{Ca}^{2+}$ reuptake in vitro. Furthermore, in vivo analysis of antimiR-29 administration restores cardiac contractility in a cardiomyopathy mouse model caused by HIF1apha deficiency [104].

On the other hand indirect targeting evidences have been provided for miR-21 [105], miR-208b [89], miR-22 [106], miR-214 [107], miR-1954 [108], miR-376b, miR-1, miR-26a, miR-30d, and miR-181c [109] (Figure 1B). miR-21 overexpression leads to increased calcium transients amplitude, yet no biochemical assays of direct SERCA interactions are reported [105]. miR-208b expression displays inverse correlations with SERCA levels, $\mathrm{I}_{\mathrm{Ca}, \mathrm{L}}$ density and miR-208b overexpression impairs calcium handling in HL1 cardiomyocytes but similarly biochemical interaction evidences are lacking [89]. miR-22 null mutants display reduced Serca2a transporting activity and lower SR Ca ${ }^{2+}$ load. Decreased Serca2a protein and mRNA expression is observed in miR-22 null mutants while Pln, Ncx, Casq2, and Ryr2 displayed no significant differences [106]. However, it remains to be elucidated the precise mechanisms of such impaired Serca2 expression and function. Finally, for miR-214 [107], miR-1954 [108], miR-376b, miR-1, miR-26a, miR-30d, and miR-181c [109] only inverse 
correlation of microRNA and Serca2 expression in distinct biological contexts are provided without any additional mechanistic proof.

Curiously, CircITCH acts as a natural sponge of miR-330-5p, thereby upregulating SERCA2 and opening novel ways for SERCA2A post-transcriptional regulation [119]. Additional bioinformatic approaches have investigated microRNA-SERCA2A interactions [187], yet further functional studies are needed for verification. Importantly, SERCA2A impaired expression - e.g., adenovirus mediated overexpression—also leads to microRNA deregulation, such as for miR-1 [188], supporting a fine-tuned cross-talk between ncRNAs and calcium homeostasis.

In contrast to the current evidence of SERCA2A modulation by microRNAs, scarce evidences are reported on phospholamban post-transcriptional regulation. Soller et al. [110] described that miR-1 and miR-21 can target Pln, releasing thus SERCA inhibition and also indirect evidence are available that miR-208a can modulate Pln expression [111] (Figure 1B), yet the precise electrophysiological consequences of such modulation roles in in vivo remains unanswered.

Similarly to Pln, scarce evidences are reported for Ncx1 regulation by microRNAs. Hong et al. [112] described that miR-132 targets Ncx1 and Melo et al. [107] that miR1 targets Ncx1, yet the electrophysiological consequences of such interactions remains elusive. Additional evidences have been reported in other biological settings, such as for miR-103 targeting Ncx1 in the brain [189], yet they are similarly scarce (Figure 1B). A summary of the microRNA interaction with the genes involved in CICR is provided on Table 1, while their links to distinct cardiac diseases is provided on Table 2.

\section{Conclusions and Perspectives}

The relevance of ion channels in governing normal heart rhythm is reflected by the increased incidence of arrhythmias if these ion channels are mutated and/or deregulated [35]. In this scenario, ncRNAs are essential in the maintenance of cardiac function. We have provided herein a state-of-the-art review of the current mechanisms regulated by non-coding RNAs that modulate $\mathrm{Na}^{+}, \mathrm{K}^{+}$, and $\mathrm{Ca}^{2+}$ channel expression and/or function in the cardiovascular system. Ample evidence is available on the direct functional role of microRNAs regulating all phases of the cardiac action potential, such as for example the pore-forming subunit SCN5A expression, through biochemical interaction with its 3'UTR. Importantly, mutations in the 3'UTR can alter such biochemical interactions, and thus impaired normal gene regulation, as recently demonstrated on SCN5A. Furthermore, direct biochemical evidence are also available for those $\mathrm{K}^{+}$and $\mathrm{Ca}^{2}$ channels involved in the repolarization and resting membrane potential phases of the cardiac action potential, with the exception of the $\mathrm{I}_{\mathrm{Kur}}$ current. Surprisingly, our current understanding is still very limited compared to the distinct bioinformatically predicted interactive regulatory networks (Figure 2) exemplified herein for pore forming $\mathrm{Na}+$ channels but applicable to all ion channels involved in the cardiac action potential configuration. Furthermore, such plausible interactive networks revealed an intricate number of microRNAs that can simultaneously target distinct components of the repolarization phase, supporting a plausible mechanism underlying co-regulation of the distinct phases of the cardiac action potential. Therefore, increasing efforts should be made to faithfully understand the functional role of microRNAs in cardiac electrophysiology and function, since such knowledge will empower us to better understand the etiology of distinct cardiac electrophysiological defects.

In fact, modulation of microRNA function enlightens the creation of novel therapeutic tools in cardiac electrophysiology using miRNA biology. miRNA mimics can be used to increase beneficial miRNAs expression in disease settings, such as long QT or Brugada syndromes, respectively, whereas miRNA inhibitors can be administered to block microRNA activity that drive disease progression. Supporting evidences on this front have been already reported [47]. In this context, identification and validation of miRNA targets is essential for the development of miRNA-based therapeutics [190]. It is therefore 
expected to soon see increasing evidence of the therapeutic application of microRNA-based approach in the context of cardiac arrhythmias.

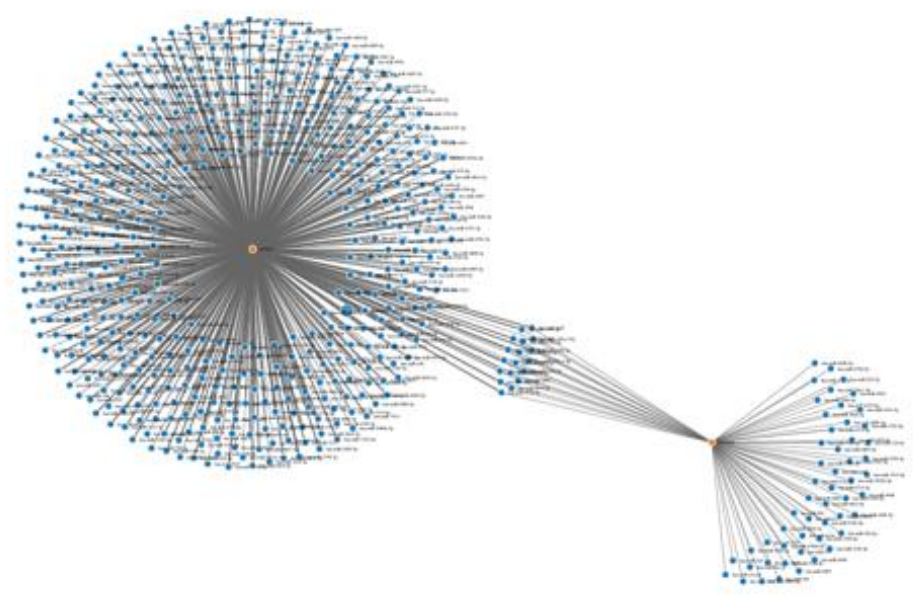

Figure 2. Plausible interactive networks of microRNA regulation on SCN5A and SCN10A as predicted using MirWalk algorithm.

On the other hand, our current understanding of the functional role of lncRNAs in cardiac action potential, and in cardiac electrophysiology at large is still incipient. Only reports on the role of MALAT1 regulating cardiac $\mathrm{I}_{\mathrm{TO}}$ current throughout the miR-200c/HMGB1 pathway [73], on LncRNA-LINC00472 acting as a miR-24 sponge and thus regulating RYR2 expression [99] and of CircITCH as a natural sponge of miR-330-5p, thereby upregulating SERCA2 [119] have been reported. Therefore, it is expected that additional evidence on the regulatory mechanisms driven by lncRNAs in cardiac electrophysiology will progressively increase in the near future.

Author Contributions: Conceptualization, E.L.-V. and D.F., data curation E.L.-V. and D.F. Writing original draft preparation, E.L.-V. and D.F., Writing-review and editing, E.L.-V., A.A. and D.F. Funding adquisition, A.A. and D.F. All authors have read and agreed to the published version of the manuscript.

Funding: This research was funded by Consejeria de Transformaci n Econ mica, Industria, Conocimiento y Universidades of the Junta de Andalucia Regional Council, grant number CTS-446.

Conflicts of Interest: The authors declare no conflict of interest.

\section{References}

1. Zipes, D.P.; Wellens, H.J.J. Sudden Cardiac Death. Circulation 1998, 98, 2334-2351. [CrossRef]

2. Van Weerd, J.H.; Christoffels, V.M. The formation and function of the cardiac conduction system. Development 2016, 143, 197-210. [CrossRef]

3. Shih, H.T. Anatomy of the action potential in the heart. Texas Heart Inst. J. 1994, 21, 30-41.

4. Nerbonne, J.M.; Kass, R.S. Molecular physiology of cardiac repolarization. Physiol. Rev. 2005, 85, 1205-1253. [CrossRef] [PubMed]

5. Bartos, D.C.; Grandi, E.; Ripplinger, C.M. Ion channels in the heart. Compr. Physiol. 2015, 5, 1423-1464. [PubMed]

6. Eisner, D.A.; Caldwell, J.L.; Kistamás, K.; Trafford, A.W. Calcium and Excitation-Contraction Coupling in the Heart. Circ. Res. 2017, 121, 181-195. [CrossRef]

7. Endo, M. Calcium-induced release of calcium from the sarcoplasmic reticulum. Am. J. Physiol. Cell Physiol. 2007, 592, $275-285$.

8. Fabiato, A. Calcium-induced release of calcium from the cardiac sarcoplasmic reticulum. Am. J. Physiol. 1983, 245, C1-C14. [CrossRef] [PubMed]

9. Milani-Nejad, N.; Janssen, P.M.L. Small and large animal models in cardiac contraction research: Advantages and disadvantages. Pharmacol. Ther. 2014, 141, 235-249. [CrossRef]

10. Vornanen, M.; Hassinen, M. Zebrafish heart as a model for human cardiac electrophysiology. Channels 2016, 10, 101-110. [CrossRef]

11. Cheng, J. Evidences of the gender-related differences in cardiac repolarization and the underlying mechanisms in different animal species and human. Fundam. Clin. Pharmacol. 2006, 20, 1-8. [CrossRef] [PubMed] 
12. McKinnon, D.; Rosati, B. Transmural gradients in ion channel and auxiliary subunit expression. Prog. Biophys Mol. Biol 2016, 122, 165-186. [CrossRef] [PubMed]

13. Barry, D.M.; Nerbonne, N.J. Myocardial potassium channels: Electrophysiological and molecular diversity. Annu. Rev. Physiol. 1996, 58, 363-394. [CrossRef] [PubMed]

14. Tanaka, H.; Namekata, I.; Nouchi, H.; Shigenobu, K.; Kawanishi, T.; Takahara, A. New aspects for the treatment of cardiac diseases based on the diversity of functional controls on cardiac muscles: Diversity in the excitation-contraction mechanisms of the heart. J. Pharmacol. Sci. 2009, 109, 327-333. [CrossRef] [PubMed]

15. Ber, D.M. Species Differences and the Role of Sodium-Calcium Exchange in Cardiac Muscle Relaxation. Ann. N. Y. Acad. Sci. 1991, 639, 375-385.

16. Carninci, P.; Kasukawa, T.; Katayama, S.; Gough, J.; Frith, M.C.; Maeda, N.; Oyama, R.; Ravasi, T.; Lenhard, C.; Wells, R.; et al. Molecular biology: The transcriptional landscape of the mammalian genome. Science 2005, 309, 1559-1563. [PubMed]

17. Harrow, J.; Frankish, A.; Gonzalez, J.M.; Tapanari, E.; Diekhans, M.; Kokocinski, F.; Aken, B.L.; Barrell, D.; Zadissa, A.; Searle, S.; et al. GENCODE: The reference human genome annotation for The ENCODE Project. Genome Res. 2012, 22, 1760-1764. [CrossRef]

18. García-Padilla, C.; Aránega, A.; Franco, D. The role of long non-coding RNAs in cardiac development and disease. AIMS Genet. 2018, 5, 124-140. [CrossRef]

19. Expósito-Villén, A.; Aránega, A.E.; Franco, D. Functional role of non-coding RNAs during epithelial-to-mesenchymal transition. Non-Coding RNA 2018, 4, 14. [CrossRef]

20. Shi, X.; Sun, M.; Liu, H.; Yao, Y.; Song, Y. Long non-coding RNAs: A new frontier in the study of human diseases. Cancer Lett. 2013, 339, 159-166. [CrossRef]

21. Esteller, M. Non-coding RNAs in human disease. Nat. Rev. Genet. 2011, 12, 861-874. [CrossRef]

22. Mattick, J.S.; Makunin, I.V. Non-coding RNA. Hum. Mol. Genet. 2006, 15, 17-29. [CrossRef]

23. Scott, M.S.; Ono, M. From snoRNA to miRNA: Dual function regulatory non-coding RNAs. Biochimie 2011, 93, 1987-1992. [CrossRef] [PubMed]

24. Ma, L.; Bajic, V.B.; Zhang, Z. On the classification of long non-coding RNAs. RNA Biol. 2013, 10, 924-933. [CrossRef] [PubMed]

25. Bartel, D.P. MicroRNAs: Genomics, Biogenesis, Mechanism, and Function. Cell 2004, 116, 281-297. [CrossRef]

26. Bartel, D.P. MicroRNA Target Recognition and Regulatory Functions. Cell 2009, 136, 215-233. [CrossRef]

27. Bartel, D.P. Metazoan MicroRNAs. Cell 2018, 173, 20-51. [CrossRef]

28. Singh, S.R.; Rameshwar, P. MicroRNA in Development and in the Progression of Cancer; Springer Science \& Business: Berlin, Germany, 2014; ISBN1 978-1-4899-8064-9. ISBN2 978-1-4899-8065-6. (eBook).

29. Lu, M.; Zhang, Q.; Deng, M.; Miao, J.; Guo, Y.; Gao, W.; Cui, Q. An analysis of human microRNA and disease associations. PLoS ONE 2008, 3, 1-5. [CrossRef] [PubMed]

30. Statello, L.; Guo, C.J.; Chen, L.L.; Huarte, M. Gene regulation by long non-coding RNAs and its biological functions. Nat. Rev. Mol. Cell Biol. 2021, 22, 96-118. [CrossRef]

31. Engreitz, J.M.; Haines, J.E.; Perez, E.M.; Munson, G.; Chen, J.; Kane, M.; McDonel, E.; Guttman, M.; Lander, E.S. Local regulation of gene expression by lncRNA promoters, transcription and splicing. Nature 2016, 539, 452-455. [CrossRef]

32. Mathieu, E.L.; Belhocine, M.; Dao, L.T.M.; Puthier, D.; Spicuglia, S. Functions of lncRNA in development and diseases. Med. Sci. 2014, 30, 790-796.

33. García-Padilla, C.; Domínguez, J.N.; Aránega, A.E.; Franco, D. Differential chamber-specific expression and regulation of long non-coding RNAs during cardiac development. BBA Gene Regul. Mech. 2019, 1862, 194435. [CrossRef]

34. Luo, S.; Lu, J.Y.; Liu, L.; Yin, Y.; Chen, C.; Han, X.; Bohou, W.; Xu, R.; Liu, W.; Yan, P.; et al. Divergent lncRNAs regulate gene expression and lineage differentiation in pluripotent cells. Cell Stem Cell 2016, 18, 637-652. [CrossRef]

35. Amin, A.S.; Tan, H.L.; Wilde, A.A.M. Cardiac ion channels in health and disease. Heart Rhythm 2010, 7, 117-126. [CrossRef] [PubMed]

36. Remme, C.A. Cardiac sodium channelopathy associated with SCN5A mutations: Electrophysiological, molecular and genetic aspects. J. Physiol. 2013, 591, 4099-4116. [CrossRef] [PubMed]

37. Amin, A.S.; Asghari-Roodsari, A.; Tan, H.L. Cardiac sodium channelopathies. Pflugers Arch. Eur. J. Physiol. 2010, 460, 223-237. [CrossRef]

38. Pérez-Agustín, A.; Pinsach-Abuin, M.L.; Pagans, S. Role of non-coding variants in brugada syndrome. Int. J. Mol. Sci. 2020, 21, 8556. [CrossRef] [PubMed]

39. Splawski, I.; Shen, J.; Timothy, K.W.; Lehmann, M.H.; Priori, S.; Robinson, J.L.; Moss, A.J.; Schwartz, P.J.; Towbin, J.A.; Vincent, G.M.; et al. Spectrum of mutations in Long-QT Syndrome genes: KVLQT1, HERG, SCN5A, KCNE1, and KCNE2. Circulation 2000, 102, 1178-1185. [CrossRef]

40. Bezzina, C.R.; Barc, J.; Mizusawa, Y.; Remme, C.A.; Gourraud, J.B.; Simonet, F.; Verkerk, A.O.; Schwartz, P.J.; Crotti, L.; Dagradi, F.; et al. Common variants at SCN5A-SCN10A and HEY2 are associated with Brugada syndrome, a rare disease with high risk of sudden cardiac death. Nat. Genet. 2013, 45, 1044-1049. Available online: https://www.ncbi.nlm.nih.gov/pmc/articles/PMC362 4763/pdf/nihms412728.pdf (accessed on 25 June 2021). [CrossRef]

41. Gando, I.; Williams, N.; Fishman, G.I.; Sampson, B.A.; Tang, Y.; Coetzee, W.A. Functional characterization of SCN10A variants in several cases of sudden unexplained death. Forensic Sci. Int. 2019, 301, 289-298. [CrossRef] 
42. Delaney, J.T.; Muhammad, R.; Shi, Y.; Schildcrout, J.S.; Blair, M.; Short, L.; Roden, D.M.; Darbar, D. Common SCN10A variants modulate PR interval and heart rate response during atrial fibrillation. Europace 2014, 16, 485-490. [CrossRef]

43. Savio-Galimberti, E.; Weeke, P.; Muhammad, R.; Blair, M.; Ansari, S.; Short, L.; Atack, T.C.; Kor, K.; Vanoye, C.G.; Olesen, M.S.; et al. SCN10A/Nav1.8 modulation of peak and late sodium currents in patients with early onset atrial fibrillation. Cardiovasc. Res. 2014, 104, 355-363. [CrossRef] [PubMed]

44. Hu, D.; Barajas-Martínez, H.; Pfeiffer, R.; Dezi, F.; Pfeiffer, J.; Buch, T.; Betzenhauser, M.J.; Belardinelli, L.; Kahlig, K.M.; Rajamani, S.; et al. Mutations in SCN10A are responsible for a large fraction of cases of brugada syndrome. J. Am. Coll. Cardiol. 2014, 64, 66-79. [CrossRef] [PubMed]

45. Monasky, M.M.; Micaglio, E.; Vicedomini, G.; Locati, E.T.; Ciconte, G.; Giannelli, L.; Giordano, F.; Crisa, S.; Vecchi, M.; Borrelli, V.; et al. Comparable clinical characteristics in Brugada syndrome patients harboring SCN5A or novel SCN10A variants. Europace 2019, 21, 1550-1558. [CrossRef] [PubMed]

46. Van Den Boogaard, M.; Smemo, S.; Burnicka-Turek, O.; Arnolds, D.E.; Van De Werken, H.J.G.; Klous, P.; McKean, D.; Muehlschlegel, J.D.; Moosmann, J.; Toka, O.; et al. A common genetic variant within SCN10A modulates cardiac SCN5A expression. J. Clin. Investig. 2014, 124, 1844-1852. [CrossRef]

47. Daimi, H.; Lozano-Velasco, E.; Haj Khelil, A.; Chibani, J.B.E.; Barana, A.; Amorós, I.; Gonzáles de la Fuente, M.; Caballero, R.; Aranega, A.; Franco, D. Regulation of SCN5A by microRNAs: miR-219 modulates SCN5A transcript expression and the effects of flecainide intoxication in mice. Heart Rhythm 2015, 12, 1333-1342. Available online: http:/ / www.ncbi.nlm.nih.gov/pubmed/25 701775 (accessed on 15 April 2016). [CrossRef] [PubMed]

48. Zhao, Y.; Huang, Y.; Li, W.; Wang, Z.; Zhan, S.; Zhou, M.; Yao, Y.; Zen, Z.; Hou, Y.; Chen, Q.; et al. Post-transcriptional regulation of cardiac sodium channel gene SCN5A expression and function by miR-192-5p. Biochim. Biophys. Acta 2015, 1852, $2024-2034$. [CrossRef]

49. Chinchilla, A.; Daimi, H.; Lozano-Velasco, E.; Dominguez, J.N.; Caballero, R.; Delpo, E.; Tamargo, J.; Cinca, J.; Hove-Madsen, L.; Aranega, A.; et al. PITX2 insufficiency leads to atrial electrical and structural remodeling linked to arrhythmogenesis. Circ. Cardiovasc. Genet. 2011, 4, 269-279. [CrossRef]

50. Poon, E.N.Y.; Hao, B.; Guan, D.; Li, M.J.; Lu, J.; Yang, Y.; Wu, B.; Wu, S.C.M.; Webb, S.E.; Liang, Y.; et al. Integrated transcriptomic and regulatory network analyses identify microRNA-200c as a novel repressor of human pluripotent stem cell-derived cardiomyocyte differentiation and maturation. Cardiovasc. Res. 2018, 114, 894-906. [CrossRef]

51. Li, J.; Xu, C.; Liu, Y.; Li, Y.; Du, S.; Zhang, R.; Sun, Y.; Zhang, R.; Wang, Y.; Xue, H.; et al. Fibroblast growth factor 21 inhibited ischemic arrhythmias via targeting miR-143/EGR1 axis. Basic Res. Cardiol. 2020, 115, 9. [CrossRef]

52. Zhang, X.; Yoon, J.Y.; Morley, M.; McLendon, J.M.; Mapuskar, K.A.; Gutmann, R.; Mehdi, H.; Bloom, H.L.; Dudley, S.C.; Ellinor, P.T.; et al. A common variant alters SCN5A-miR-24 interaction and associates with heart failure mortality. J. Clin. Investig. 2018, 128, 1154-1163. [CrossRef]

53. Daimi, H.; Khelil, A.H.; Neji, A.; Ben Hamda, K.; Maaoui, S.; Aranega, A.; Chibani, J.B.; Franco, D. Role of SCN5A coding and non-coding sequences in Brugada syndrome onset: What's behind the scenes? Biomed. J. 2019, 42, 252-260. [CrossRef]

54. Tan, Y.X.; Hong, Y.; Jiang, S.; Lu, M.N.; Li, S.; Chen, B.; Zhang, L.; Hu, T.; Mao, R.; Mei, R.; et al. MicroRNA-449a regulates the progression of brain aging by targeting SCN2B in SAMP8 mice. Int. J. Mol. Med. 2020, 45, 1091-1102. [CrossRef]

55. Brandenburger, T.; Johannsen, L.; Prassek, V.; Kuebart, A.; Raile, J.; Wohlfromm, S.; Kohrer, K.; Huhn, R.; Hollmann, M.W.; Hermanns, H. MiR-34a is differentially expressed in dorsal root ganglia in a rat model of chronic neuropathic pain. Neurosci. Lett. 2019, 708, 134365. [CrossRef] [PubMed]

56. Chen, J.; Zhao, X.; Cui, L.; He, G.; Wang, X.; Wang, F.; Duan, S.; He, L.; Li, Q.; Yu, X.; et al. Genetic regulatory subnetworks and key regulating genes in rat hippocampus perturbed by prenatal malnutrition: Implications for major brain disorders. Aging $\mathbf{2 0 2 0}$ 12, 8434-8458. [CrossRef] [PubMed]

57. Norcini, M.; Choi, D.; Lu, H.; Cano, M.; Piskoun, B.; Hurtado, A.; Sideris, A.; Blanck, T.J.J.; Recio-Pinto, E. Intrathecal Injection of miR-133b-3p or miR-143-3p Prevents the Development of Persistent Cold and Mechanical Allodynia Following a Peripheral Nerve Injury in Rats. Neuroscience 2018, 386, 223-239. [CrossRef] [PubMed]

58. Salunkhe, V.A.; Esguerra, J.L.S.; Ofori, J.K.; Mollet, I.G.; Braun, M.; Stoffel, M.; Wendt, A.; Eliasson, L. Modulation of microRNA375 expression alters voltage-gated $\mathrm{Na}+$ channel properties and exocytosis in insulin-secreting cells. Acta Physiol. 2015, 213, 882-892. [CrossRef]

59. Huang, H.; Qing, X.Y.; Zhou, Q.; Li, H.D.; Hu, Z.Y. Silencing of microRNA-3175 represses cell proliferation and invasion in prostate cancer by targeting the potential tumor-suppressor SCN4B. Kaohsiung J. Med. Sci. 2021, 37, 20-26. [CrossRef]

60. Dai, W.; Zhou, J.; Wang, H.; Zhang, M.; Yang, X.; Song, W. miR-424-5p promotes the proliferation and metastasis of colorectal cancer by directly targeting SCN4B. Pathol Res. Pract. 2020, 216, 152731. [CrossRef]

61. Zhao, J.; Lee, M.C.; Momin, A.; Cendan, C.M.; Shepherd, S.T.; Baker, M.D.; Asante, C.; Bee, L.; Berthy, A.; Perkins, J.R.; et al. Small RNAs control sodium channel expression, nociceptor excitability, and pain thresholds. J. Neurosci. 2010, 30, 10860-10871. [CrossRef]

62. Yan, J.; Yu, H.; Shen, J.; Han, C.; Li, C.; Shen, X.; Li, B. Early over-expressing of microRNA-145 effectively precludes the development of neuropathic mechanical hyperalgesia via suppressing Nav1.8 in diabetic rats. Pain Physician 2020, 23, E673-E686. 
63. D'Souza, A.; Pearman, C.M.; Wang, Y.; Nakao, S.; Logantha, S.J.R.J.; Cox, C.; Bennett, H.; Zhang, Y.; Johnsen, A.B.; Linscheid, N.; et al. Targeting miR-423-5p Reverses Exercise Training-Induced HCN4 Channel Remodeling and Sinus Bradycardia. Circ. Res. 2017, 121, 1058-1068. [CrossRef] [PubMed]

64. Yanni, J.; D’Souza, A.; Wang, Y.; Li, N.; Hansen, B.J.; Zakharkin, S.O.; Smith, M.; Hayward, C.; Whitson, B.; Mohler, P.J.; et al. Silencing miR-370-3p rescues funny current and sinus node function in heart failure. Sci. Rep. 2020, 10, 11279. [CrossRef] [PubMed]

65. Petkova, M.; Atkinson, A.J.; Yanni, J.; Stuart, L.; Aminu, A.J.; Ivanova, A.D.; Pustovit, K.B.; Geragthy, C.; Feather, A.; Li, N.; et al. Identification of Key Small Non-Coding MicroRNAs Controlling Pacemaker Mechanisms in the Human Sinus Node. J. Am. Heart Assoc. 2020, 9, e016590. [CrossRef]

66. Li, Y.D.; Hong, Y.F.; Yusufuaji, Y.; Tang, B.P.; Zhou, X.H.; Xu, G.J.; Li, J.X.; Sun, L.; Zhang, J.H.; Xin, Q.; et al. Altered expression of hyperpolarization-activated cyclic nucleotide-gated channels and microRNA-1 and -133 in patients with age-associated atrial fibrillation. Mol. Med. Rep. 2015, 12, 3243-3248. [CrossRef]

67. Suffredini, S.; Stillitano, F.; Comini, L.; Bouly, M.; Brogioni, S.; Ceconi, C.; Ferrati, R.; Mugelli, A.; Cerbai, E. Long-term treatment with ivabradine in post-myocardial infarcted rats counteracts f-channel overexpression. Br. J. Pharmacol. 2012, 165, 1457-1466. [CrossRef] [PubMed]

68. Yu, H.D.; Xia, S.; Zha, C.Q.; Deng, S.B.; Du, J.L.; She, Q. Spironolactone Regulates HCN Protein Expression Through Micro-RNA-1 in Rats with Myocardial Infarction. J. Cardiovasc. Pharmacol. 2015, 65, 587-592. [CrossRef]

69. D'souza, A.; Bucchi, A.; Johnsen, A.B.; Logantha, S.J.R.J.; Monfredi, O.; Yanni, J.; Prehar, S.; Hart, G.; Cartwright, E.; Wisloff, U.; et al. Exercise training reduces resting heart rate via downregulation of the funny channel HCN4. Nat. Commun. 2014, 5, 3775. [CrossRef]

70. Zhao, Y.; Ransom, J.F.; Li, A.; Vedantham, V.; von Drehle, M.; Muth, A.N.; Tsuchihashi, T.; McManus, M.T.; Schwartz, R.J.; Srivastava, D. Dysregulation of Cardiogenesis, Cardiac Conduction, and Cell Cycle in Mice Lacking miRNA-1-2. Cell 2007, 129, 303-317. [CrossRef]

71. Liu, X.; Zhang, Y.; Du, W.; Liang, H.; He, H.; Zhang, L.; Pan, Z.; Li, X.; Xu, C.; Zhou, Y.; et al. MiR-223-3p as a Novel MicroRNA Regulator of Expression of Voltage-Gated K + Channel Kv4.2 in Acute Myocardial Infarction. Cell Physiol. Biochem. 2016, 39 , 102-114. [CrossRef]

72. Nassal, D.M.; Wan, X.; Liu, H.; Maleski, D.; Ramirez-Navarro, A.; Moravec, C.S.; Ficker, E.; LAurita, K.; Deschenes, I. KChIP2 is a core transcriptional regulator of cardiac excitability. Elife 2017, 6, 1-24. [CrossRef] [PubMed]

73. Zhu, P.; Yang, M.; Ren, H.; Shen, G.; Chen, J.; Zhang, J.; Liu, J.; Sun, C. Long noncoding RNA MALAT1 downregulates cardiac transient outward potassium current by regulating miR-200c/HMGB1 pathway. J. Cell Biochem. 2018, 119, 10239-10249. [CrossRef] [PubMed]

74. Mondejar-Parreño, G.; Callejo, M.; Barreira, B.; Morales-Cano, D.; Esquivel-Ruiz, S.; Moreno, L.; Cogolludo, A.; Perez-Vizcaino, F. miR-1 is increased in pulmonary hypertension and downregulates Kv1.5 channels in rat pulmonary arteries. J. Physiol. 2019, 597, 1185-1197. [CrossRef]

75. Lian, J.; Guo, J.; Huang, X.; Yang, X.; Huang, G.; Mao, H.; Sun, H.H.; Ba, Y.; Zhou, J. miRNAs Regulate hERG. J. Cardiovasc. Electrophysiol. 2016, 27, 1472-1482. [CrossRef] [PubMed]

76. Li, Y.; Yang, C.M.; Xi, Y.; Wu, G.; Shelat, H.; Gao, S.; Cheng, J.; Geng, Y.J. MicroRNA-1/133 targeted dysfunction of potassium channels KCNE1 and KCNQ1 in human cardiac progenitor cells with simulated hyperglycemia. IJC 2013, 167, 1076-1078. [CrossRef] [PubMed]

77. Jia, X.; Zheng, S.; Xie, X.; Zhang, Y.; Wang, W.; Wang, Z.; Zhang, Y.; Wang, J.; Gao, M.; Hou, Y. MicroRNA-1 accelerates the shortening of atrial effective refractory period by regulating KCNE1 and KCNB2 expression: An atrial tachypacing rabbit model PLoS ONE 2013, 8. Available online: https:/ / pubmed.ncbi.nlm.nih.gov/24386485/ (accessed on 11 December 2020). [CrossRef]

78. Yang, B.; Lin, H.; Xiao, J.; Lu, Y.; Luo, X.; Li, B.; Zhang, Y.; Xu, C.; Bai, Y.; Wang, H.; et al. The muscle-specific microRNA miR-1 regulates cardiac arrhythmogenic potential by targeting GJA1 and KCNJ2. Nat. Med. 2007, 13, 486-491. [CrossRef]

79. Girmatsion, Z.; Biliczki, P.; Bonauer, A.; Wimmer-Greinecker, G.; Scherer, M.; Moritz, A.; Bukowska, A.; Goetter, A.; Nattel, S.; Hohnloser, S.H.; et al. Changes in microRNA-1 expression and IK1 up-regulation in human atrial fibrillation. Heart Rhythm 2009, 6, 1802-1809. [CrossRef]

80. Li, X.; Hu, H.; Wang, Y.; Xue, M.; Li, X.; Cheng, W.; Xuan, Y.; Yin, J.; Yang, N.; Yan, S. Valsartan ameliorates KIR2.1 in rats with myocardial infarction via the NF-kB-miR-16 pathway. Gene 2016, 590, 201-209. [CrossRef]

81. Luo, X.; Pan, Z.; Shan, H.; Xiao, J.; Sun, X.; Wang, N.; Lin, X.; Xiao, L.; Maguy, A.; Qi, X.Y.; et al. MicroRNA-26 governs profibrillatory inward-rectifier potassium current changes in atrial fibrillation. JCI 2013, 123, 1939-1951. Available online: https:/ / pubmed.ncbi.nlm.nih.gov /23543060/ (accessed on 11 December 2020). [CrossRef]

82. Qi, X.Y.; Huang, H.; Ordog, B.; Luo, X.; Naud, P.; Sun, Y.; Wu, C.T.; Dawson, K.; Tadevosyan, A.; Chen, Y.; et al. Fibroblast inward-rectifier potassium current upregulation in profibrillatory atrial Remodeling. Circ. Res. 2015, 116, 836-845. [CrossRef]

83. Thum, T.; Galuppo, P.; Wolf, C.; Fiedler, J.; Kneitz, S.; Van Laake, L.W.; Doevendans, P.A.; Mummery, C.L.; Borlak, J.; Haverich, A.; et al. MicroRNAs in the human heart: A clue to fetal gene reprogramming in heart failure. Circulation 2007, 116, 258-267. [CrossRef] 
84. Goldoni, D.; Yarham, J.M.; McGahon, M.K.; O'Connor, A.; Guduric-Fuchs, J.; Edgar, K.; McDonald, D.M.; Simpson, D.A.; Collins, A. A novel dual-fluorescence strategy for functionally validating microRNA targets in $3^{\prime}$ untranslated regions: Regulation of the inward rectifier potassium channel Kir2.1 by miR-212. Biochem. J. 2012, 448, 103-113. [CrossRef]

85. Zhang, X.J.; Liao, C.X.; Sun, K.J.; Liu, L.L.; Xu, D.Y. A soluble epoxide hydrolase inhibitor upregulated kcnj12 and kcnip2 by downregulating microrna-29 in a mouse model of myocardial infarction. Heart Surg. Forum. 2020, 23, E579-E585. [CrossRef]

86. Binas, S.; Knyrim, M.; Hupfeld, J.; Kloeckner, U.; Rabe, S.; Mildenberger, S.; Quarch, K.; Stratz, N.; Misiak, D.; Gekle, M.; et al. miR-221 and -222 target CACNA1C and KCNJ5 leading to altered cardiac ion channel expression and current density. CLMS 2019, 77, 903-918. [CrossRef]

87. Lu, Y.; Zhang, Y.; Wang, N.; Pan, Z.; Gao, X.; Zhang, F.; Zhang, Y.; Shan, H.; Luo, X.; Bai, Y.; et al. MicroRNA-328 contributes to adverse electrical remodeling in atrial fibrillation. Circulation 2010, 122, 2378-2387. [CrossRef]

88. Barana, A.; Matamoros, M.; Dolz-Gaitón, P.; Pérez-Hernández, M.; Amorós, I.; Núñez, M.; Sacristan, S.; Pedraz, A.; Pinto, A.; Fernandez-Aviles, F.; et al. Chronic atrial fibrillation increases MicroRNA-21 in human atrial myocytes decreasing L-type calcium current. Circ. Arrhythmia Electrophysiol. 2014, 7, 861-868. [CrossRef] [PubMed]

89. Cañón, S.; Caballero, R.; Herraiz-Martínez, A.; Pérez-Hernández, M.; López, B.; Atienza, F.; Jalife, J.; Hove-Madsen, L.; Delpon, E.; Bernard, A. miR-208b upregulation interferes with calcium handling in HL-1 atrial myocytes: Implications in human chronic atrial fibrillation. J. Mol. Cell Cardiol. 2016, 99, 162-173. [CrossRef] [PubMed]

90. Zhao, Y.; Yuan, Y.; Qiu, C. Underexpression of CACNA1C caused by overexpression of microRNA-29a underlies the pathogenesis of atrial fibrillation. Med. Sci. Monit. 2016, 22, 2175-2181. [CrossRef]

91. Ling, T.Y.; Wang, X.L.; Chai, Q.; Lu, T.; Stulak, J.M.; Joyce, L.D.; Daly, R.C.; Greason, K.L.; Wu, L.Q.; Shen, W.K.; et al. Regulation of cardiac CACNB2 by microRNA-499: Potential role in atrial fibrillation. BBA Clin. 2017, 7, 78-84. [CrossRef] [PubMed]

92. Chu, Q.; Li, A.; Chen, X.; Qin, Y.; Sun, X.; Li, Y.; Yue, E.; Wang, C.; Ding, X.; Yan, Y.; et al. Overexpression of miR-135b attenuates pathological cardiac hypertrophy by targeting CACNA1C. Int. J. Cardiol. 2018, 269, 235-241. [CrossRef]

93. Liu, Z.; Tao, B.; Fan, S.; Pu, Y.; Xia, H.; Xu, L. MicroRNA-145 protects against myocardial ischemia reperfusion injury via CaMKII-mediated antiapoptotic and anti-inflammatory pathways. Oxid. Med. Cell Longev. 2019, 10, 8948657. [CrossRef]

94. Chiang, D.Y.; Kongchan, N.; Beavers, D.L.; Alsina, K.M.; Voigt, N.; Neilson, J.R.; Jakob, H.; Martin, J.F.; Dobrev, D.; Wehrens, X.H.T.; et al. Loss of MicroRNA-106b-25 cluster promotes atrial fibrillation by enhancing ryanodine receptor type-2 expression and calcium release. Circ. Arrhythmia Electrophysiol. 2014, 7, 1214-1222. [CrossRef]

95. Li, Q.; Qin, M.; Tan, Q.; Li, T.; Gu, Z.; Huang, P.; Ren, L. MicroRNA-129-1-3p protects cardiomyocytes from pirarubicin-induced apoptosis by down-regulating the GRIN2D-mediated Ca2+ signalling pathway. J. Cell Mol. Med. 2020, 24, 2260-2271. [CrossRef]

96. Belevych, A.E.; Sansom, S.E.; Terentyeva, R.; Ho, H.T.; Nishijima, Y.; Martin, M.M.; Jindal, H.K.; Rochira, J.A.; Kunimoto, Y.; Abdellatif, M.; et al. MicroRNA-1 and -133 increase arrhythmogenesis in heart failure by dissociating phosphatase activity from RyR2 complex. PLoS ONE 2011, 6, e28324. [CrossRef]

97. Terentyev, D.; Belevych, A.E.; Terentyeva, R.; Martin, M.M.; Malana, G.E.; Kuhn, D.E.; Abdellatif, M.; Feldman, D.S.; Elton, T.S.; Gyorke, S. MiR-1 Overexpression Enhances Ca2+ release and Promotes Cardiac Arrhythmogenesis by Targeting PP2A Regulatory Subunit B56 $\alpha$ and Causing CaMKII-Dependent Hyperphosphorylation of RyR2. Circ Res. 2009, 104, 514-521. [CrossRef] [PubMed]

98. Li, R.C.; Tao, J.; Guo, Y.B.; Wu, H.D.; Liu, R.F.; Bai, Y.; LV, Z.Z.; Luo, G.Z.; Li, L.L.; Wang, M.; et al. In vivo suppression of microRNA-24 prevents the transition toward decompensated hypertrophy in aortic-constricted mice. Circ. Res. 2013, 112, 601-605. [CrossRef] [PubMed]

99. Wang, L.-Y.; Shen, H.; Yang, Q.; Min, J.; Wang, Q.; Xi, W.; Yin, L.; Le, S.G.; Zhang, Y.F.; Xiao, J.; et al. LncRNA-LINC00472 contributes to the pathogenesis of atrial fibrillation (Af) by reducing expression of JP2 and RyR2 via miR-24. Biomed. Pharmacother. 2019, 120, 109364. [CrossRef] [PubMed]

100. Jeong, D.; Yoo, J.; Lee, P.; Kepreotis, S.V.; Lee, A.; Wahlquist, C.; Brown, B.D.; Kho, C.; Mercola, M.; Hajjar, R.J. miR-25 Tough Decoy Enhances Cardiac Function in Heart Failure. Mol. Ther. 2018, 7, 718-729. [CrossRef]

101. Wahlquist, C.; Jeong, D.; Rojas-Muñoz, A.; Kho, C.; Lee, A.; Mitsuyama, S.; van Mil, A.; Park, W.J.; Sluijter, J.P.G.; Doevendans, P.A.F.; et al. Inhibition of miR-25 improves cardiac contractility in the failing heart. Nature 2014, 508, 531-535. [CrossRef]

102. Li, C.; Li, X.; Gao, X.; Zhang, R.; Zhang, Y.; Liang, H.; Xu, C.; Du, W.; Zhang, Y.; Liu, X.; et al. MicroRNA-328 as a regulator of cardiac hypertrophy. Int. J. Cardiol. 2014, 173, 268-276. [CrossRef] [PubMed]

103. Zheng, X.; Hu, X.; Ge, T.; Li, M.; Shi, M.; Luo, J.; Lai, H.; Nie, T.; Li, F.; Li, H. MicroRNA-328 is involved in the effect of selenium on hydrogen peroxide-induced injury in H9c2 cells. J. Biochem. Mol. Toxicol. 2017, 31, 3-9. [CrossRef]

104. Williams, A.L.; Walton, C.B.; MacCannell, K.A.; Avelar, A.; Shohet, R.V. HIF1 regulation of miR-29c impairs SERCA2 expression and cardiac contractility. AJPheart. 2019, 53, 21-25. Available online: http:/ / doi.org/10.1152/ajpheart.00617.2018 (accessed on 25 June 2021).

105. Mayourian, J.; Ceholski, D.K.; Gorski, P.A.; Mathiyalagan, P.; Murphy, J.F.; Salazar, S.I.; Stillitano, F.; Hare, J.M.; Sahoo, S.; Hajjar, R.J.; et al. Exosomal microRNA-21-5p Mediates Mesenchymal Stem Cell Paracrine Effects on Human Cardiac Tissue Contractility. Circ. Res. 2018, 122, 933-944. [CrossRef] [PubMed]

106. Gurha, P.; Abreu-Goodger, C.; Wang, T.; Ramirez, M.O.; Drumond, A.L.; Van Dongen, S.; Chen, Y.; Bartonicek, N.; Enright, A.J.; Lee, B.; et al. Targeted deletion of MicroRNA-22 promotes stress-induced cardiac dilation and contractile dysfunction. Circulation 2012, 125, 2751-2761. [CrossRef] [PubMed] 
107. Melo, S.F.S.; Barauna, V.G.; Neves, V.J.; Fernandes, T.; Lara, L.d.S.; Mazzotti, D.R. Exercise training restores the cardiac microRNA-1 and -214 levels regulating Ca2+ handling after myocardial infarction. BMC Cardiovasc. Disord. 2015, 15, 4-11. [CrossRef]

108. Chiasson, V.; Takano, A.P.C.; Guleria, R.S.; Gupta, S. Deficiency of MicroRNA miR-1954 Promotes Cardiac Remodeling and Fibrosis. J. Am. Heart Assoc. 2019, 8, 1-13. [CrossRef]

109. Mishra, P.K.; Metreveli, N.; Tyagi, S.C. MMP-9 gene ablation and TIMP-4 mitigate PAR-1-mediated cardiomyocyte dysfunction A plausible role of dicer and miRNA. Cell Biochem. Biophys. 2010, 57, 67-76. [CrossRef]

110. Soller, K.J.; Yang, J.; Veglia, G.; Bowser, M.T. Reversal of phospholamban inhibition of the sarco(endo)plasmic reticulum Ca2+ATPase (SERCA) using short, protein-interacting RNAs and oligonucleotide analogs. J. Biol. Chem. 2016, 291, 21510-21518. [CrossRef]

111. Bedada, F.B.; Martindale, J.J.; Arden, E.; Metzger, J.M. Molecular inotropy mediated by cardiac miR-based PDE4D/PRKAR1 $\alpha /$ phosphoprotein signaling. Sci. Rep. 2016, 6, 36803. [CrossRef]

112. Hong, S.; Lee, J.; Seo, H.H.; Lee, C.Y.; Yoo, K.J.; Kim, S.M.; Lee, S.; Hwang, K.C.; Choi, E. Na+-Ca2+ exchanger targeting miR-132 prevents apoptosis of cardiomyocytes under hypoxic condition by suppressing Ca2+ overload. Biochem. Biophys. Res. Commun. 2015, 460, 931-937. [CrossRef]

113. Curran, M.E.; Splawski, I.; Timothy, K.W.; Vincen, G.M.; Green, E.D.; Keating, M.T. A molecular basis for cardiac arrhythmia: HERG mutations cause long QT syndrome. Cell 1995, 80, 795-803. [CrossRef]

114. Mourad, N.A.-R. Microrna Regulation of Herg-Related Current: Potential Role in Heart Failure-Associated Arrhythmias [Internet] Purdue University, 2015. Available online: https:/ / docs.lib.purdue.edu/dissertations/AAI10188989/ (accessed on 25 June 2021).

115. Takumi, T.; Ohkubo, H.; Nakanishi, S. Cloning of a membrane protein that induces a slow voltage-gated potassium current. Science 1988, 242, 1042-1045. [CrossRef]

116. Barhanin, J.; Lesage, F.; Guillemare, E.; Fink, M.; Lazdunski, M.; Romey, G. K(V)LQT1 and IsK (minK) proteins associate to form the I(Ks) Cardiac Potassium Current. Nature 1996, 384, 78-80. [CrossRef] [PubMed]

117. Sanguinetti, M.C.; Curran, M.E.; Zou, A.; Shen, J.; Spector, P.S.; Atkinson, D.L.; Keating, M. Coaseembly of KvLQT1 and minK (IsK) proteins to form cardiac Iks potassium channel. Lett. Nat. 1996, 384, 80-83. [CrossRef] [PubMed]

118. Zhu, H.; Xue, H.; Jin, Q.H.; Guo, J.; Chen, Y.D. Increased expression of ryanodine receptor type-2 during atrial fibrillation by miR-106-25 cluster independent mechanism. Exp. Cell Res. 2019, 375, 113-117. [CrossRef] [PubMed]

119. Han, D.; Wang, Y.; Wang, Y.; Dai, X.; Zhou, T.; Chen, J.; Tao, B.; Zhang, J.; Cao, F. The Tumor-Suppressive Human Circular RNA CircITCH Sponges miR-330-5p to Ameliorate Doxorubicin-Induced Cardiotoxicity through Upregulating SIRT6, Survivin, and SERCA2a. Circ. Res. 2020, 127, E108-E125. [CrossRef]

120. DiFrancesco, D.; Borer, J.S. The Funny Current. Drugs 2007, 67 (Suppl. S2), 15-24. [CrossRef]

121. Yu, S.Y.; Na, J.Y.; Lee, Y.J.; Kim, K.T.; Park, J.T.; Kim, H.S. Forensic application of microRNA-706 as a biomarker for drowning pattern identification. Forensic Sci. Int. 2015, 255, 96-101. [CrossRef]

122. Abriel, H. Cardiac sodium channel Nav1.5 and interacting proteins: Physiology and pathophysiology. J. Mol. Cell Cardiol. 2010, 48, 2-11. [CrossRef]

123. Shy, D.; Gillet, L.; Abriel, H. Cardiac sodium channel NaV1.5 distribution in myocytes via interacting proteins: The multiple pool model. Biochim. Biophys. Acta 2013, 1833, 886-894. [CrossRef] [PubMed]

124. Chazin, W.J.; Johnson, C.N. Calmodulin mutations associated with heart arrhythmia: A status report. Int. J. Mol. Sci. 2020, 21, 1418. [CrossRef] [PubMed]

125. Takla, M.; Huang, C.L.H.; Jeevaratnam, K. The cardiac CaMKII-Nav1.5 relationship: From physiology to pathology. J. Mol. Cell Cardiol. 2020, 139, 190-200. [CrossRef] [PubMed]

126. Panneerselvam, M.; Patel, H.H.; Roth, D.M. Caveolins and HEart Diseases, Caveolins and Caveolae. In Caveolins and Caveolae Advances in Experimental Medicine and Biology; Springer Science+Business Media: Berlin, Germany, 2012; Volume 729, pp. 145-156. ISBN 978-1-4614-1221-2.

127. Balijepalli, R.C.; Kamp, T.J. Caveolae, Ion Channels and Cardiac Arrhythmias Ravi. Prog. Biophys. Mol. Biol. 2008, 98, 149-160. [CrossRef]

128. Greer-Short, A.; Musa, H.; Alsina, K.M.; Ni, L.; Word, T.A.; Reynolds, J.O.; Gratz, D.; Lane, C.; El-Refaey, M.; Unudurthu, S.; et al. Calmodulin kinase II regulates atrial myocyte late sodium current, calcium handling, and atrial arrhythmia. Heart Rhythm 2020, 17, 503-511. [CrossRef] [PubMed]

129. Wang, Z.; Vermij, S.H.; Sottas, V.; Shestak, A.; Ross-Kaschitza, D.; Zaklyazminskaya, E.V.; Hudmon, A.; Pitt, G.S.; Rougier, J.S.; Abriel, H. Calmodulin binds to the N-terminal domain of the cardiac sodium channel Nav1.5. Channels 2020, 14, 268-286. [CrossRef] [PubMed]

130. Gabelli, S.B.; Boto, A.; Kuhns, V.H.; Bianchet, M.A.; Farinelli, F.; Aripirala, S.; Yoder, J.; Jakoncic, J.; Tomaselli, G.F.; Amzel, L.M. Regulation of the NaV 1.5 cytoplasmic domain by calmodulin. Nat. Commun. 2014, 5, 1-11. [CrossRef] [PubMed]

131. Gabelli, S.B.; Yoder, J.B.; Tomaselli, G.F.; Amzel, L.M. Calmodulin and $\mathrm{Ca}^{2+}$ control of voltage gated Na+ channels. Channels 2016, 10, 45-54. [CrossRef]

132. Johnson, C.N.; Pattanayek, R.; Potet, F.; Rebbeck, R.T.; Blackwell, D.J.; Nikolaienko, R.; Sequeria, V.; Le Meur, R.; Radwanski, P.B.; Davis, J.P.; et al. The CaMKII inhibitor KN93-calmodulin interaction and implications for calmodulin tuning of NaV1.5 and RyR2 function. Cell Calcium 2019, 82, 102063. [CrossRef] 
133. Gardill, B.R.; Rivera-Acevedo, R.E.; Tung, C.C.; Van Petegem, F. Crystal structures of Ca ${ }^{2+}$-Calmodulin bound to NaV C-terminal regions suggest role for EF-hand domain in binding and inactivation. Proc Natl Acad Sci. USA 2019, 166, 10763-10772. [CrossRef]

134. Koval, O.M.; Snyder, J.S.; Wolf, R.M.; Pavlovicz, R.E.; Glynn, P.; Curran, J.; Leymaster, N.D.; Dun, W.; Wright, P.J.; Cardona, N.; et al. $\mathrm{Ca}^{2+} /$ calmodulin-dependent protein kinase ii-based regulation of voltage-gated na+ channel in cardiac disease. Circulation 2012, 126, 2084-2094. [CrossRef] [PubMed]

135. Ashpole, N.M.; Herren, A.W.; Ginsburg, K.S.; Brogan, J.D.; Johnson, D.E.; Cummins, T.R.; Bers, D.M.; Hudmon, A. $\mathrm{Ca} 2+$ /calmodulin-dependent protein kinase II (CaMKII) regulates cardiac sodium channel NaV1.5 gating by multiple phosphorylation sites. J. Biol. Chem. 2012, 287, 19856-19869. [CrossRef] [PubMed]

136. Ikeda, S.; He, A.; Kong, S.W.; Lu, J.; Bejar, R.; Bodyak, N.; Lee, K.H.; Ma, Q.; Kang, P.M.; Golub, T.R.; et al. MicroRNA-1 negatively regulates expression of the hypertrophy-associated calmodulin and Mef2a genes. Mol. Cell Biol. 2009, 29, 2193-2204. [CrossRef] [PubMed]

137. Zhou, X.; Sun, F.; Luo, S.; Zhao, W.; Yang, T.; Zhang, G.; Gao, M.; Lu, R.; Shu, Y.; Mu, W.; et al. Let-7a is an antihypertrophic regulator in the heart via targeting calmodulin. Int. J. Biol. Sci. 2017, 13, 22-31. [CrossRef] [PubMed]

138. Cai, K.; Chen, H. MiR-625-5p Inhibits Cardiac Hypertrophy through Targeting STAT3 and CaMKII. Hum. Gene Ther. Clin. Dev. 2019, 30, 182-191. [CrossRef] [PubMed]

139. Zhang, Y.; Hou, Y.; Gao, F.M.; Xiao, J.; Li, C.W.; Tang, Y.C. IncRNA GAS5 regulates myocardial infarction by targeting the miR-525-5p/CALM2 axis. J. Cell Biochem. 2019, 120, 18678-18688. [CrossRef]

140. Li, K.; Lin, Y.; Li, C. MiR-338-5p ameliorates pathological cardiac hypertrophy by targeting CAMKII $\delta$. Arch Pharm. Res. 2019, 42, 1071-1080. [CrossRef]

141. Kim, J.O.; Song, D.W.; Kwon, E.J.; Hong, S.E.; Song, H.K.; Min, C.K.; Kim, D.H. MiR-185 plays an anti-hypertrophic role in the heart via multiple targets in the calcium-signaling pathways. PLoS ONE 2015, 13, e0122509. [CrossRef]

142. Cha, M.J.; Jang, J.K.; Ham, O.; Song, B.W.; Lee, S.Y.; Lee, C.Y.; Park, J.H.; Lee, J.; Seo, H.H.; Choi, E.; et al. MicroRNA-145 suppresses ROS-induced Ca2+ overload of cardiomyocytes by targeting CaMKII $\delta$. Biochem. Biophys. Res. Commun. 2013, 435, 720-726. [CrossRef]

143. He, J.; Jiang, S.; Li, F.L.; Zhao, X.J.; Chu, E.F.; Sun, M.N.; Chen, M.Z.; Li, H. MicroRNA-30b-5p is involved in the regulation of cardiac hypertrophy by targeting CaMKII $\delta$. J. Investig. Med. 2013, 61, 604-612. [CrossRef]

144. Liu, P.Y.; Tian, Y.; Xu, S.Y. Mediated protective effect of electroacupuncture pretreatment by miR-214 on myocardial ischemia/reperfusion injury. J. Geriatr. Cardiol. 2014, 11, 303-310.

145. Qi, X.Y.; Hassani, F.V.; Hoffmann, D.; Xiao, J.; Xiong, F.; Villeneuve, L.R.; Ljubojevic-Holzer, S.; Kamler, M.; Abu-Taha, I.; Heijman, J.; et al. Inositol Trisphosphate Receptors and Nuclear Calcium in Atrial Fibrillation. Circ. Res. 2021, 128, 619-635. [CrossRef]

146. Vatta, M.; Ackerman, M.J.; Ye, B.; Makielski, J.C.; Ughanze, E.E.; Taylor, E.W.; Tester, D.J.; Balijepali, R.C.; Foell, J.D.; Li, Z.; et al. Mutant caveolin-3 induces persistent late sodium current and is associated with long-QT syndrome. Circulation 2006, 114, 2104-2112. [CrossRef]

147. Cheng, J.; Valdivia, C.R.; Vaidyanathan, R.; Balijepalli, R.C.; Ackerman, M.J.; Makielski, J.C. Caveolin-3 suppresses late sodium current by inhibiting nNOS-dependent S-nitrosylation of SCN5A. JMCC 2013, 61, 102-110. [CrossRef]

148. Chen, Z.; Qi, Y.; Gao, C. Cardiac myocyte-protective effect of microRNA-22 during ischemia and reperfusion through disrupting the caveolin-3/eNOS signaling. Int. J. Clin. Exp. Pathol. 2015, 8, 4614-4626. [PubMed]

149. Zhang, L.; Yin, H.; Jiao, L.; Liu, T.; Gao, Y.; Shao, Y.; Zhang, Y.; Shan, H.; Zhang, Y.; Yang, B. Abnormal Downregulation of Caveolin-3 Mediates the Pro-Fibrotic Action of MicroRNA-22 in a Model of Myocardial Infarction. Cell Physiol. Biochem. 2018, 45, 1641-1653. [CrossRef]

150. Casini, S.; Marchal, G.A.; Kawasaki, M.; Nariswari, F.A.; Portero, V.; van den Berg, N.W.E.; Guan, K.; Driessen, A.H.G.; Veldkamp, M.W.; Mengarelli, I.; et al. Absence of Functional Nav1.8 Channels in Non-diseased Atrial and Ventricular Cardiomyocytes. Cardiovasc. Drugs Ther. 2019, 33, 649-660. [CrossRef] [PubMed]

151. Tang, B.; Hu, Y.; Wang, Z.; Cheng, C.; Wang, P.; Liang, L.; Xiong, H.; Luo, C.; Xu, C.; Chen, Q.; et al. UBC9 regulates cardiac sodium channel Na v 1.5 ubiquitination, degradation and sodium current density. JMCC 2019, 129, 79-91. [CrossRef]

152. Minegishi, S.; Ishigami, T.; Kawamura, H.; Kino, T.; Chen, L.; Nakashima-Sasaki, R.; Doi, H.; Azushima, K.; Wakui, H.; Chiba, Y.; et al. An isoform of Nedd4-2 plays a pivotal role in electrophysiological cardiac abnormalities. Int. J. Mol. Sci. 2017, 18, 1268. [CrossRef]

153. Zhu, J.; Heidersbach, A.; Kathiriya, I.S.; Garay, B.I.; Ivey, K.N.; Srivastava, D.; Han, Z.; King, I.N. The E3 ubiquitin ligase Nedd4/Nedd4L is directly regulated by microRNA 1. Development 2017, 144, 866-875. [CrossRef] [PubMed]

154. Zeng, J.; Laurita, K.R.; Rosenbaum, D.S.; Rudy, Y. Two Components of the Delayed Rectifier K+ Current in Ventricular Myocytes of the Guinea Pig Type. Circ. Res. 1995, 77, 140-152. [CrossRef]

155. Wettwer, E.; Amos, G.; Gath, J.; Zerkowski, H.R.; Reidemeister, J.C.; Ravens, U. Transient outward current in human and rat ventricular myocytes. Cardiovasc. Res. 1993, 27, 1662-1669. [CrossRef]

156. Grant, A.O. Cardiac ion channels. Circ. Arrhythmia Electrophysiol. 2009, 2, 185-194. [CrossRef] [PubMed]

157. Niwa, N.; Nerbonne, J.M. Molecular determinants of cardiac transient outward potassium current (Ito) expression and regulation. J. Mol. Cell Cardiol. 2010, 48, 12-25. [CrossRef] [PubMed]

158. Grubb, S.; Calloe, K.; Thomsen, M.B. Impact of KChiP2 on cardiac electrophysiology and the progression of heart failure. Front. Physiol. 2012, 3, 118. [CrossRef] [PubMed] 
159. Feng, J.; Xu, D.; Wang, Z.; Nattel, S. Ultrarapid delayed rectifier current inactivation in human atrial myocytes: Properties and consequences. Am. J. Physiol. Heart Circ. Physiol. 1998, 275, 1-3. [CrossRef] [PubMed]

160. Rampe, D.; Wang, Z.; Fermini, B.; Wible, B.; Dage, R.C.; Nattel, S. Voltage- and time-dependent block by perhexiline of K+ currents in human atrium and in cells expressing a Kv1.5-type cloned channel. J. Pharmacol. Exp. Ther. 1995, 274, 444-449. [PubMed]

161. Sanguinetti, M.C.; Jiang, C.; Curran, M.E.; Keating, M.T. A mechanistic link between an inherited and an acquird cardiac arrthytmia: HERG encodes the IKr potassium channel. Cell 1995, 81, 299-307. [CrossRef]

162. Warmke, J.W.; Ganetzky, B. A family of potassium channel genes related to eag in Drosophila and mammals. Proc Natl Acad Sci. USA 1994, 91, 3438-3442. [CrossRef]

163. Abbott, G.W.; Sesti, F.; Splawski, I.; Buck, M.E.; Lehmann, M.H.; Timothy, K.W.; Keating, M.T.; Goldstein, S.A. MiRP1 forms IKr potassium channels with HERG and is associated with cardiac arrhythmia. Cell 1999, 97, 175-187. [CrossRef]

164. Wang, Y.; Wang, L.; Yin, C.; An, B.; Hao, Y.; Wei, T.; Li, L.; Song, G. Arsenic trioxide inhibits breast cancer cell growth via microRNA-328/hERG pathway in MCF-7 cells. Mol. Med. Rep. 2015, 12, 1233-1238. [CrossRef]

165. Assiri, A.A.; Mourad, N.; Shao, M.; Kiel, P.; Liu, W.; Skaar, T.C.; Overholser, B.R. MicroRNA 362-3p reduces hERG-related current and inhibits breast cancer cells proliferation. Cancer Genom. Proteom. 2019, 16, 433-442. [CrossRef]

166. Wang, Q.; Curran, M.E.; Splawski, I.; Burn, T.C.; Millholland, J.M.; VanRaay, T.J.; Shen, J.; Timothy, K.W.; Vincent, G.M.; de Jager, T.; et al. Positional cloning of a novel potassium channel gene: KVLQT1 mutations cause cardiac arrhythmias. Nat. Genet. 1996, 12, 17-23. [CrossRef]

167. Brahmajothi, M.V.; Morales, M.J.; Liu, S.; Rasmusson, R.L.; Campbell, D.L.; Strauss, H.C. In Situ Hybridization Reveals Extensive Diversity of K+ Channel mRNA in Isolated Ferret Cardiac Myocytes. Circ. Res. 1996, 76, 1083-1089. [CrossRef]

168. Chen, L.; Sampson, K.J.; Kass, R.S. Cardiac Delayed Rectifier Potassium Channels in Health and Disease. Card. Electrophysiol. Clin. 2016, 8, 307-322. [CrossRef]

169. Tristani-Firouzi, M.; Chen, J.; Mitcheson, J.S.; Sanguinetti, M.C. Molecular biology of K+ channels and their role in cardiac arrhythmias. Am. J. Med. 2001, 110, 50-59. [CrossRef]

170. Dhamoon, A.S.; Jalife, J. The inward rectifier current (IK1) controls cardiac excitability and is involved in arrhythmogenesis. Heart Rhythm 2005, 2, 316-324. [CrossRef]

171. Shattock, M.J.; Ottolia, M.; Bers, D.M.; Blaustein, M.P.; Boguslavskyi, A.; Bossuyt, J.; Bridge, J.H.B.; Chen-Izu, Y.; Clancy, C.E.; Edwards, A.; et al. $\mathrm{Na}^{+} / \mathrm{Ca}^{2+}$ exchange and $\mathrm{Na}+/ \mathrm{K}+-A T P a s e$ in the heart. J. Physiol. 2015, 593, 1361-1382. [CrossRef] [PubMed]

172. Schwinger, R.H.G.; Bundgaard, H.; Muller-ehmsen, J.; Kjeldsen, K. The Na, K-ATPase in the failing human heart. Card. Res. 2003, 57, 913-920. [CrossRef]

173. Lichtstein, D. Na+, K(+)-ATPase and heart excitability. Adv. Exp. Med. Biol. 1995, 382, 23-30.

174. Bundgaard, H.; Kjeldsen, K. Human myocardial Na,K-ATPase concentration in heart failure. Mol. Cell Biochem. 1996, 163-164, 277-283. [CrossRef]

175. Liu, L.; Wu, J.; Kennedy, D.J. Regulation of cardiac remodeling by cardiac Na+/K+-ATPase isoforms. Front. Physiol. 2016, 7, 382. [CrossRef]

176. Shao, Q.; Ren, B.; Elimban, V.; Tappia, P.S.; Takeda, N.; Dhalla, N.S. Modification of sarcolemmal Na+-K+-ATPase and Na+/Ca ${ }^{2+}$ exchanger expression in heart failure by blockade of renin-angiotensin system. Am. J. Physiol. Heart Circ. Physiol. 2005, 288, 2637-2646. [CrossRef]

177. Ostadal, P.; Elmoselhi, A.B.; Zdobnicka, I.; Lukas, A.; Chapman, D.; Dhalla, N.S. Ischemia-reperfusion alters gene expression of $\mathrm{Na}+\mathrm{K}+$ ATPase isoforms in rat heart. Biochem. Biophys. Res. Commun. 2003, 306, 457-462. [CrossRef]

178. Yalcin, Y.; Carman, D.; Shao, Y.; Ismail-Beigi, F.; Klein, I.; Ojamaa, K. Regulation of Na/K-ATPase gene expression by thyroid hormone and hyperkalemia in the heart. Thyroid 1999, 9, 53-59. [CrossRef]

179. Schwinger, R.H.G.; Wang, J.; Frank, K.; Müller-Ehmsen, J.; Brixius, K.; McDonough, A.A.; Erdmann, E. Reduced sodium pump $\alpha 1, \alpha 3$, and $\beta 1$-isoform protein levels and $\mathrm{Na}+, \mathrm{K}+$-ATPase activity but unchanged $\mathrm{Na}+-\mathrm{Ca}^{2+}$ exchanger protein levels in human heart failure. Circulation 1999, 99, 2105-2112. [CrossRef] [PubMed]

180. Zaremba, L.S.; Smolenski, W.H. Optimal portfolio choice under a liability constraint. Ann. Oper. Res. 2000, 97, 131-141. [CrossRef]

181. Vér, Á.; Szántó, I.; Bányász, T.; Csermely, P.; Végh, E.; Somogyi, J. Changes in the expression of Na+/K+-ATPase isoenzymes in the left ventricle of diabetic rat hearts: Effect of insulin treatment. Diabetologia 1997, 40, 1255-1262. [CrossRef]

182. Drummond, C.A.; Fan, X.; Haller, S.T.; Kennedy, D.J.; Liu, J.; Tian, J. Na/K-ATPase signaling mediates miR-29b-3p regulation and cardiac fibrosis formation in mice with chronic kidney disease. PLoS ONE 2018, 13, e0197688. [CrossRef]

183. Drummond, C.A.; Hill, M.C.; Shi, H.; Fan, X.; Xie, J.X.; Haller, S.T.; KEnnedy, D.J.; Liu, J.; Garrett, M.R.; Xie, Z.; et al. Na/K-ATPase signaling regulates collagen synthesis through microRNA-29b-3p in cardiac fibroblasts. Physiol. Genom. 2016, 48, 220-229. [CrossRef]

184. Zhang, Y.; Sun, L.; Zhang, Y.; Liang, H.; Li, X.; Cai, R.; Wang, L.; Du, W.; Zhang, R.; Li, J.; et al. Overexpression of microRNA-1 causes atrioventricular block in rodents. Int. J. Biol. Sci. 2013, 9, 445-462. [CrossRef] [PubMed]

185. Zhang, J.; Wei, F.; Ding, L.; Wang, L.; Zhang, X.; Yu, L.; Liu, R.; Kuang, X.; Jiao, B.; Yang, B.; et al. MicroRNA-1976 regulates degeneration of the sinoatrial node by targeting Cav1.2 and Cav1.3 ion channels. J. Mol. Cell Cardiol. 2019, 134, 74-85. [CrossRef] [PubMed]

186. Liu, Z.; Tao, B.; Fan, S.; Cui, S.; Pu, Y.; Qiu, L.; Xia, H.; Xu, L. Over-expression of microRNA-145 drives alterations in $\beta$-adrenergic signaling and attenuates cardiac remodeling in heart failure post myocardial infarction. Aging 2020, 12, 11603-11622. [CrossRef] 
187. Boštjančič, E.; Zidar, N.; Glavač, D. MicroRNAs and cardiac sarcoplasmic reticulum calcium ATPase-2 in human myocardial infarction: Expression and bioinformatic analysis. BMC Genomics 2012, 15, 552. [CrossRef] [PubMed]

188. Kumarswamy, R.; Lyon, A.R.; Volkmann, I.; Mills, A.M.; Bretthauer, J.; Pahuja, A.; Geers-Knorr, C.; Kraft, T.; Hajjar, R.J.; Macleod, K.T.; et al. SERCA2a gene therapy restores microRNA-1 expression in heart failure via an Akt/FoxO3A-dependent pathway. Eur. Heart J. 2012, 33, 1067-1075. [CrossRef] [PubMed]

189. Vinciguerra, A.; Formisano, L.; Cerullo, P.; Guida, N.; Cuomo, O.; Esposito, A.; Di Renzo, G.; Annunziato, L.; Pignataro, G. MicroRNA-103-1 selectively downregulates brain NCX1 and its inhibition by anti-miRNA ameliorates stroke damage and neurological deficits. Mol. Ther. 2014, 22, 1829-1838. [CrossRef] [PubMed]

190. Kim, G.H. MicroRNA regulation of cardiac conduction and arrhythmias. Transl. Res. 2013, 161, 381-392. [CrossRef] 